\title{
Predictions of the glass transition temperature and viscosity of organic aerosols from volatility distributions
}

\author{
Ying Li ${ }^{1}$, Douglas A. Day ${ }^{2,3}$, Harald Stark ${ }^{2,3,4}$, Jose L. Jimenez ${ }^{2,3}$, and Manabu Shiraiwa ${ }^{1}$ \\ ${ }^{1}$ Department of Chemistry, University of California, Irvine, CA 92697-2025, USA \\ ${ }^{2}$ Cooperative Institute for Research in Environmental Sciences (CIRES), University of Colorado, Boulder, CO 80309, USA \\ ${ }^{3}$ Department of Chemistry, University of Colorado, Boulder, CO 80309, USA \\ ${ }^{4}$ Aerodyne Research Inc., Billerica, MA 01821, USA
}

Correspondence: Ying Li (yingl47@uci.edu) and Manabu Shiraiwa (m.shiraiwa@uci.edu)

Received: 10 December 2019 - Discussion started: 6 January 2020

Revised: 10 June 2020 - Accepted: 21 June 2020 - Published: 13 July 2020

\begin{abstract}
Volatility and viscosity are important properties of organic aerosols (OA), affecting aerosol processes such as formation, evolution, and partitioning of OA. Volatility distributions of ambient OA particles have often been measured, while viscosity measurements are scarce. We have previously developed a method to estimate the glass transition temperature $\left(T_{\mathrm{g}}\right)$ of an organic compound containing carbon, hydrogen, and oxygen. Based on analysis of over 2400 organic compounds including oxygenated organic compounds, as well as nitrogen- and sulfur-containing organic compounds, we extend this method to include nitrogen- and sulfur-containing compounds based on elemental composition. In addition, parameterizations are developed to predict $T_{\mathrm{g}}$ as a function of volatility and the atomic oxygento-carbon ratio based on a negative correlation between $T_{\mathrm{g}}$ and volatility. This prediction method of $T_{\mathrm{g}}$ is applied to ambient observations of volatility distributions at 11 field sites. The predicted $T_{\mathrm{g}}$ values of OA under dry conditions vary mainly from 290 to $339 \mathrm{~K}$ and the predicted viscosities are consistent with the results of ambient particle-phase-state measurements in the southeastern US and the Amazonian rain forest. Reducing the uncertainties in measured volatility distributions would improve predictions of viscosity, especially at low relative humidity. We also predict the $T_{\mathrm{g}}$ of OA components identified via positive matrix factorization of aerosol mass spectrometer (AMS) data. The predicted viscosity of oxidized OA is consistent with previously reported viscosity of secondary organic aerosols (SOA) derived from $\alpha$-pinene, toluene, isoprene epoxydiol (IEPOX), and diesel fuel. Comparison of the predicted viscosity based on the ob-
\end{abstract}

served volatility distributions with the viscosity simulated by a chemical transport model implies that missing low volatility compounds in a global model can lead to underestimation of OA viscosity at some sites. The relation between volatility and viscosity can be applied in the molecular corridor or volatility basis set approaches to improve OA simulations in chemical transport models by consideration of effects of particle viscosity in OA formation and evolution.

\section{Introduction}

Organic aerosols (OA) contribute substantially to the mass loadings of atmospheric fine particulate matter (Hallquist et al., 2009; Jimenez et al., 2009). OA formed from various anthropogenic or biogenic precursors have complex physicochemical properties (Goldstein and Galbally, 2007; Nizkorodov et al., 2011; Ditto et al., 2018), which makes predictions of their role in air quality, climate, and public health challenging (Kanakidou et al., 2005; Shrivastava et al., 2017). Volatility and viscosity are important properties of OA, both of which affect important aerosol processes such as gas-particle partitioning, new particle formation and evolution of size distribution, heterogeneous reactions, and cloud condensation and ice nucleation pathways of OA, as summarized in recent review articles (Krieger et al., 2012; Bilde et al., 2015; Pöschl and Shiraiwa, 2015; Knopf et al., 2018; Reid et al., 2018).

Recent measurements have shown that OA can exist in liquid (low dynamic viscosity $\eta ; \eta<10^{2} \mathrm{~Pa}$ ), semisolid 
$\left(10^{2} \leq \eta \leq 10^{12} \mathrm{Pas}\right)$, and amorphous solid $\left(\eta>10^{12} \mathrm{Pas}\right)$ states, depending on temperature $(T)$, relative humidity (RH), and chemical composition (Reid et al., 2018). Even though there are several particle bounce measurements to infer ambient OA phase state, there are limited ambient measurements of particle phase state or viscosity (Virtanen et al., 2010; O'Brien et al., 2014; Bateman et al., 2016, 2017; Pajunoja et al., 2016; Liu et al., 2017; Ditto et al., 2019; Slade et al., 2019). Viscosity can be directly converted to bulk diffusivity of organic molecules using the Stokes-Einstein equation, which has been shown to work well for organic molecules diffusing through low-viscosity materials (Price et al., 2016; Chenyakin et al., 2017). This relation is inapplicable for predicting the bulk diffusivity of water and small molecules, and it may also underestimate the diffusivity of organic molecules in a highly viscous matrix, which can be corrected using a fractional Stokes-Einstein equation (Price et al., 2016; Evoy et al., 2019).

Viscosity can be related to the glass transition temperature $\left(T_{\mathrm{g}}\right)$, at which a phase transition between amorphous solid and semisolid states occurs (Koop et al., 2011). Ambient temperature varies through $100 \mathrm{~K}$ throughout the troposphere, greatly influencing the viscosity of the mixture. When the ambient temperature is below $T_{\mathrm{g}}$, an amorphous particle behaves as a solid, while a particle would be semisolid or liquid when the ambient temperature is above $T_{\mathrm{g}}$. OA particles contain a number of organic compounds and also a variable amount of liquid water depending on RH, which can act as a plasticizer to reduce $T_{\mathrm{g}}$ : these mixture effects can be estimated using the Gordon-Taylor relation (Mikhailov et al., 2009; Koop et al., 2011; Dette et al., 2014). In addition, ambient OA may often be internally mixed with inorganic species such as sulfate and nitrate, which would further lower $T_{\mathrm{g}}$ and viscosity if they were well mixed in one phase; when the phase separation occurs, the inorganic-rich and organic-rich phases may undergo glass transition at different temperatures (Dette and Koop, 2015).

For pure organic compounds with known molecular structure, viscosity can be predicted by group contribution approaches (Cao et al., 1993; Bosse, 2005; Y. C. Song et al., 2016; Rovelli et al., 2019; Gervasi et al., 2020); chemical composition of ambient OA is complex, and molecular specificity is often unavailable, which makes viscosity predictions of ambient OA challenging. We have recently developed a set of semiempirical parameterizations using molar mass $(M)$ and atomic O : C ratio (Shiraiwa et al., 2017) or elemental composition (DeRieux et al., 2018) to predict $T_{\mathrm{g}}$ for compounds comprised of carbon, hydrogen, and oxygen $(\mathrm{CHO}$ compounds). These parameterizations have been applied to high-resolution mass spectrometry measurements to estimate viscosity of organic aerosols (DeRieux et al., 2018; Schum et al., 2018; Ditto et al., 2019; Song et al., 2019) and coupled into a thermodynamic model (Gervasi et al., 2020). Note that heteroatoms and the effects of molecular structure and func- tional groups on $T_{\mathrm{g}}$ are not considered in parameterizations of Shiraiwa et al. (2017) and DeRieux et al. (2018).

Viscosity of pure compounds has been found to be inversely correlated with vapor pressure (Thomas et al., 1979). The molecular-corridor-based analysis (Shiraiwa et al., 2014; $\mathrm{Li}$ et al., 2016) of hundreds of secondary organic aerosol (SOA) components has shown that compounds with lower pure-compound saturation mass concentration $\left(C^{0}\right)$ have higher $T_{\mathrm{g}}$ (Shiraiwa et al., 2017). Rothfuss and Petters (2017) found that there is a similar trend between the sensitivity of viscosity to functional group addition and the sensitivity of vapor pressure to functional group addition. Measurements of the evaporation kinetics of maleic acid showed that decreasing particle viscosity leads to a suppression in the effective vapor pressure of maleic acid (Marshall et al., 2018). Champion et al. (2019) found that SOA with higher condensed-phase fractions of extremely low volatility organic compounds (ELVOC) and low volatility organic compounds (LVOC) showed an increased viscosity. Zhang et al. (2019) measured $T_{\mathrm{g}}$ of isoprene SOA components including isoprene hydroxy hydroperoxide (ISOPOOH), isoprene-derived epoxydiol (IEPOX), 2-methyltetrols, and 2methyltetrol sulfates (2-MT-OS), observing a tight correlation between $T_{\mathrm{g}}$ and vapor pressure.

Based on the above evidence showing a close relation between volatility and viscosity, in this study we develop the parameterizations predicting $T_{\mathrm{g}}$ as a function of $C^{0}$ based on data from over 2000 compounds. Functional group contribution approaches are often used to predict $C^{0}$ (Capouet and Müller, 2006; Pankow and Asher, 2008; Compernolle et al., 2011; O'Meara et al., 2014); thereby, using $C^{0}$ to predict $T_{\mathrm{g}}$ would include the molecular structure effect indirectly. The developed parameterizations are applied to field observations of volatility distributions to predict viscosity of ambient OA.

\section{Methods}

\subsection{Dataset of glass transition temperature}

The training dataset used to develop the parameterizations of $T_{\mathrm{g}}$ include 2448 organic compounds classified into four classes (see the number of $\mathrm{CH}, \mathrm{CHO}, \mathrm{CHON}$, and $\mathrm{CHOS}$ compounds in Table $\mathrm{S} 1$ in the Supplement). Measured $T_{\mathrm{g}}$ values are available for $42 \mathrm{CH}$ compounds, $259 \mathrm{CHO}$ compounds, 35 CHON compounds, and 1 CHOS compound (Koop et al., 2011; Rothfuss and Petters, 2017; Lessmeier et al., 2018; Zhang et al., 2019), among which there are 168 compounds with measured $C^{0}$ available (Table S1). When $T_{\mathrm{g}}$ measurements are unavailable, $T_{\mathrm{g}}$ is estimated from the melting temperature $\left(T_{\mathrm{m}}\right)$ by applying the BoyerKauzmann rule of $T_{\mathrm{g}}=g \cdot T_{\mathrm{m}}$ (Kauzmann, 1948; Boyer, 1954) with $g=0.70085( \pm 0.00375)$ (Koop et al., 2011), referred to as "estimated $T_{\mathrm{g}}$ " in this study (see good agreement of measured and estimated $T_{\mathrm{g}}$ in Fig. S1a in the Sup- 
plement). There are 1187 compounds (391 CH, $537 \mathrm{CHO}$, $241 \mathrm{CHON}$, and 18 CHOS compounds) with both measured $T_{\mathrm{m}}$ and $C^{0}$ (Tables S1, S2) adopted from the MPBPWIN program test sets (http://esc.syrres.com/interkow/EpiSuiteData. htm, last access: 9 July 2020) included in the EPI Suite software version 4.1 (Estimation Programs Interface; US EPA, 2015). Measured $T_{\mathrm{g}}, T_{\mathrm{m}}$, or $C^{0}$ for CHOS compounds is sparse and we adopt $850 \mathrm{CHOS}$ compounds included in $\mathrm{Li}$ et al. (2016) with their $T_{\mathrm{m}}$ and $C^{0}$ estimated by the EPI Suite software (Table S2). There are estimation limitations in the EPI Suite; for example, the disagreement between measured and estimated $C^{0}$ is larger for compounds with $C^{0}<\sim 10^{-2} \mu \mathrm{g} \mathrm{m}^{-3}$ (Fig. S1b), which may affect the $T_{\mathrm{g}}$ predictions for compounds with low volatility. However, given the large number of data points with measured $C^{0}$ included in the training dataset, the estimation bias introduced by the EPI Suite may not substantially impact the accuracy of the parameterization developed in this study.

The test dataset used to validate the performance of the parameterizations predicting $T_{\mathrm{g}}$ of SOA components includes $654 \mathrm{CHO}$ compounds and $212 \mathrm{CHON}$ compounds found in SOA oxidation products (Shiraiwa et al., 2014). The values of their $C^{0}$ are estimated using the EVAPORATION model (Compernolle et al., 2011). Their $T_{\mathrm{m}}$ values are adopted from the EPI Suite. The $T_{\mathrm{g}}$ values predicted by our parameterizations are compared with the $T_{\mathrm{g}}$ estimated from the $T_{\mathrm{m}}$ by applying the Boyer-Kauzmann rule in the test dataset.

\subsection{Parameterizations of $\boldsymbol{T}_{\mathrm{g}}$ as a function of volatility}

Figure 1a shows a dependence of $T_{\mathrm{g}}$ on $C^{0}$ for 2448 organic compounds in the training dataset. The compounds with lower $C^{0}$ have higher $T_{\mathrm{g}}$, and the $T_{\mathrm{g}}$ appears to level off at around $420 \mathrm{~K}$ at $C^{0}<\sim 10^{-10} \mu \mathrm{g} \mathrm{m}^{-3}$. The dependence of $T_{\mathrm{g}}$ on the atomic $\mathrm{O}: \mathrm{C}$ ratio is weaker (Figs. 1a and $\mathrm{S} 2$ ), in agreement with previous studies (Koop et al., 2011; Shiraiwa et al., 2017). Note that a tight correlation between $T_{\mathrm{g}}$ and the $\mathrm{O}: \mathrm{C}$ ratio has been observed for oxidation products formed from specific precursors including $\alpha$-pinene (Dette et al., 2014), $n$-heptadecane, and naphthalene (Saukko et al., 2012). Based on the trend shown in Fig. 1a, we develop a parameterization (Eq. 1) to predict $T_{\mathrm{g}}$ as a function of $C^{0}$ and $\mathrm{O}: \mathrm{C}$, which are the parameters used in the two-dimensional volatility basis set (2D-VBS) framework (Donahue et al., 2011).

$$
\begin{aligned}
T_{\mathrm{g}}= & 289.10-16.50 \times \log _{10}\left(C^{0}\right)-0.29 \times\left[\log _{10}\left(C^{0}\right)\right]^{2} \\
& +3.23 \times \log _{10}\left(C^{0}\right)(\mathrm{O}: \mathrm{C})
\end{aligned}
$$

The coefficients in Eq. (1) are obtained by fitting the $T_{\mathrm{g}}$ of 2448 compounds in Fig. 1a with multilinear least squares analysis with $68 \%$ prediction and confidence intervals. The predicted $T_{\mathrm{g}}$ by Eq. (1) is plotted in Fig. 1a with the $\mathrm{O}: \mathrm{C}$ ratios of $0,0.5$, and 1 , showing that the predicted dependence of $T_{\mathrm{g}}$ on $C^{0}$ follows the trend well in the training dataset. The
$\mathrm{O}: \mathrm{C}$ ratio mainly affects the predicted $T_{\mathrm{g}}$ of volatile compounds or extremely low volatility compounds. Figure $1 \mathrm{~b}$ shows that the $T_{\mathrm{g}}$ values of those compounds are predicted well by Eq. (1) as indicated by a high correlation coefficient $(R)$ of 0.92 . The average absolute value of the relative error (AAVRE; Aiken et al., 2007) is $12 \%$.

Equation (1) is further evaluated using the test dataset for SOA components. Figure 1c compares $T_{\mathrm{g}}$ predicted by Eq. (1) with estimated $T_{\mathrm{g}}$ from $T_{\mathrm{m}}$ by applying the BoyerKauzmann rule, showing that Eq. (1) also presents a good performance for predicting $T_{\mathrm{g}}$ of these SOA components with $R=0.96$ and AAVRE $=6 \%$. Note that $C^{0}$ values of SOA components were estimated using the EVAPORATION model (Compernolle et al., 2011). The $T_{\mathrm{g}}$ values of individual SOA compounds can be predicted within $\pm 20 \mathrm{~K}$ as indicated by the prediction band (dotted lines in Fig. 1c); however, this uncertainty may be much smaller for multicomponent SOA mixtures under ideal mixing conditions as indicated in the confidence band (dashed lines, almost overlapping with the $1: 1$ line) (Shiraiwa et al., 2017; DeRieux et al., 2018; Song et al., 2019).

We also develop a parameterization (Eq. 2) predicting $T_{\mathrm{g}}$ as a function of $C^{0}$ solely, which can be applied to the information available with the one-dimensional VBS framework (1D-VBS; Donahue et al., 2006), and this can be used when the $\mathrm{O}: \mathrm{C}$ ratio is not available in measurements.

$$
T_{\mathrm{g}}=288.70-15.33 \times \log _{10}\left(C^{0}\right)-0.33 \times\left[\log _{10}\left(C^{0}\right)\right]^{2}
$$

The coefficients in Eq. (2) are obtained following the procedures developing Eq. (1) and the same training dataset is used. Figures S3-S4 show that Eq. (2) gives very similar predictions as Eq. (1) particularly for the compounds with low $\mathrm{O}: \mathrm{C}$ ratio. As Eqs. (1) and (2) are developed based on the compounds with their $C^{0}$ higher than $\sim 10^{-20} \mu \mathrm{g} \mathrm{m}{ }^{-3}$, Eqs. (1) and (2) may not be applicable for compounds with $C^{0}<\sim 10^{-20} \mu_{g^{-3}}$ (Fig. 1a).

\subsection{Predictions of $T_{\mathrm{g}}$ and viscosity of organic aerosols}

For the application of $T_{\mathrm{g}}$ parameterizations in field observations of volatility distributions, $T_{\mathrm{g}}$ for each volatility bin $\left(T_{\mathrm{g}, i}\right)$ is calculated by Eq. (1). The term volatility refers to the effective saturation mass concentration $\left(C^{*}\right)$, and we assume ideal thermodynamic mixing in which case $C^{*}$ is equal to $C^{0}$ (Donahue et al., 2011). Note that there may be additional uncertainty in application of $T_{\mathrm{g}}$ parameterizations (which were developed based on pure compounds) to each volatility bin representing a surrogate of complex multicomponent mixtures. The isolines in Fig. 2 show the $T_{\mathrm{g}, i}$ predicted by Eq. (1) with the $C^{*}$ and $\mathrm{O}: \mathrm{C}$ defined in the 2D-VBS framework. $T_{\mathrm{g}}$ would be below $\sim 250 \mathrm{~K}$ for intermediate volatility organic compounds (IVOC; $300<C^{0}<3 \times 10^{6} \mu \mathrm{g} \mathrm{m}^{-3}$ ), from $\sim 260$ to $290 \mathrm{~K}$ for semivolatile organic compounds (SVOC; $0.3<C^{0}<300 \mu \mathrm{g} \mathrm{m}^{-3}$ ), and higher than $300 \mathrm{~K}$ for low-volatility organic compounds (LVOC; $3 \times 10^{-4}<C^{0}<$ 

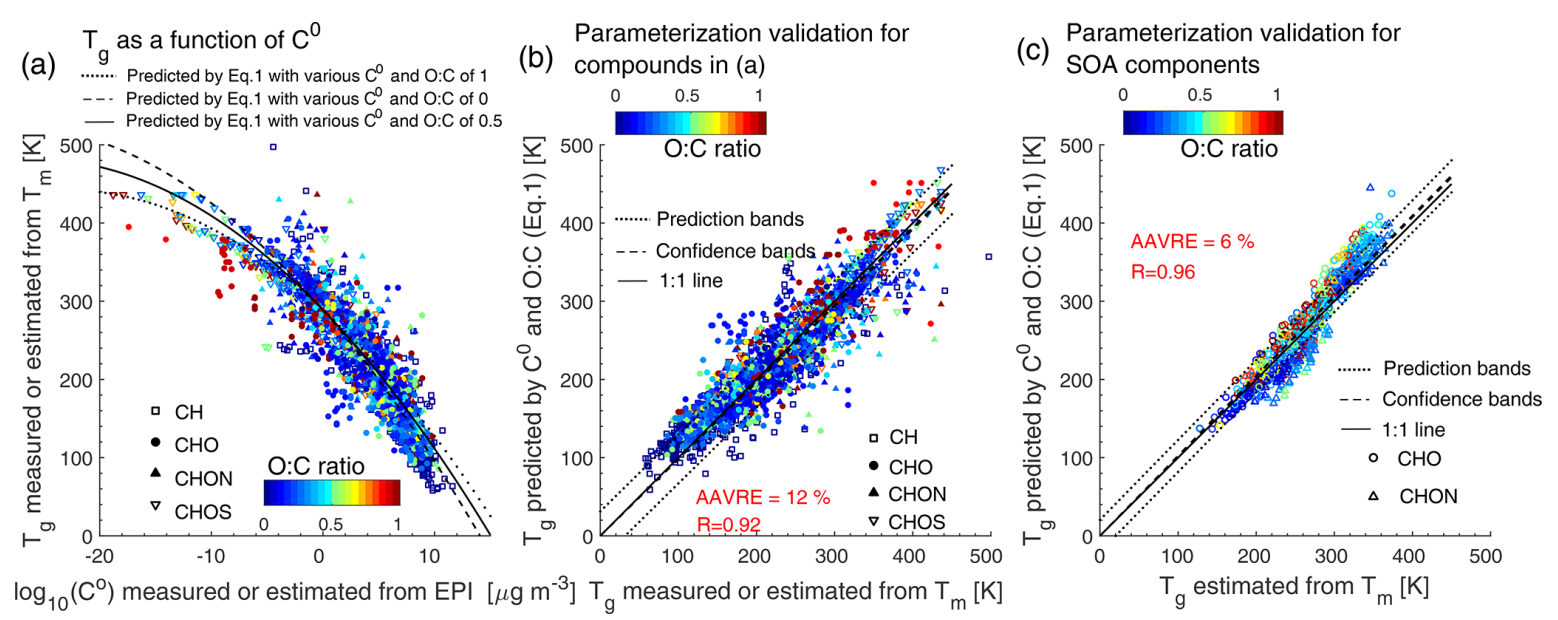

Figure 1. (a) $T_{\mathrm{g}}$ of organic compounds in the training dataset plotted against $C^{0}$. The lines show the predictions of $T_{\mathrm{g}}$ (Eq. 1) by $C^{0}$ and the $\mathrm{O}: \mathrm{C}$ ratios of 0 (dashed), 0.5 (solid), and 1 (dotted). (b) Predicted $T_{\mathrm{g}}$ by $C^{0}$ and the $\mathrm{O}: \mathrm{C}$ ratio (Eq. 1) for compounds shown in (a) compared to measured or otherwise estimated $T_{\mathrm{g}}$ from $T_{\mathrm{m}}$. (c) Predicted $T_{\mathrm{g}}$ for SOA components (Shiraiwa et al., 2014) using Eq. (1) plotted against estimated $T_{\mathrm{g}}$ from $T_{\mathrm{m}}$ with the Boyer-Kauzmann rule. The correlation coefficient $(R)$ and the average absolute value of the relative error (AAVRE) are shown. In (b) and (c) the dashed and dotted lines show $68 \%$ confidence and prediction bands, respectively.

$0.3 \mu \mathrm{g} \mathrm{m}^{-3}$ ) and extremely low volatility organic compounds (ELVOC; $C^{0}<3 \times 10^{-4} \mu \mathrm{g} \mathrm{m}^{-3}$ ). The $T_{\mathrm{g}}$ increases as the $\mathrm{O}: \mathrm{C}$ ratio increases for SVOC and IVOC, which is consistent with previous studies (Koop et al., 2011; Saukko et al., 2012; Berkemeier et al., 2014). The $T_{\mathrm{g}}$ slightly decreases as the $\mathrm{O}: \mathrm{C}$ ratio increases for $\mathrm{LVOC}$ and ELVOC compounds, which might be due to the uncertainties in Eq. (1) which is derived from a dataset containing fewer LVOC and ELVOC compounds as shown in Fig. 1a, which exhibits lower $T_{\mathrm{g}}$ with higher $\mathrm{O}: \mathrm{C}$.

The glass transition temperatures of organic aerosols under dry conditions $\left(T_{\mathrm{g}, \text { org }}\right)$ are calculated by the GordonTaylor equation (Gordon and Taylor, 1952) by assuming the Gordon-Taylor constant $\left(k_{\mathrm{GT}}\right)$ of 1 (Dette et al., 2014):

$T_{\mathrm{g}, \text { org }}=\sum_{i} w_{i} T_{\mathrm{g}, i}$,

where $w_{i}$ is the mass fraction in the particle phase for each volatility bin. The Gordon-Taylor approach has been validated for a wide range of mixtures including SOA compounds (Dette et al., 2014; Lessmeier et al., 2018). The Gordon-Taylor approach may fail in the case of adduct or complex formation (Koop et al., 2011), which is highly unlikely in multicomponent mixtures with myriads of SOA compounds with very small individual mole fractions and when particular interactions between individual compounds are more likely to average out (Shiraiwa et al., 2017); this aspect would need to be investigated in future studies.

The phase state of aerosol particles strongly depends on their water content (Mikhailov et al., 2009; Koop et al., 2011). Under humid conditions, the water content in OA can be estimated using the effective hygroscopicity parameter $(\kappa)$ (Petters and Kreidenweis, 2007). The $T_{\mathrm{g}}$ of organic-water mixtures $\left(T_{\mathrm{g}}\left(w_{\text {org }}\right)\right)$ at given $\mathrm{RH}$ can be estimated using the Gordon-Taylor equation (Gordon and Taylor, 1952):

$T_{\mathrm{g}}\left(w_{\text {org }}\right)=\frac{\left(1-w_{\text {org }}\right) T_{\mathrm{g}, \mathrm{w}}+\frac{1}{k_{\mathrm{GT}}} w_{\text {org }} T_{\mathrm{g}, \text { org }}}{\left(1-w_{\mathrm{org}}\right)+\frac{1}{k_{\mathrm{GT}}} w_{\text {org }}}$,

where $w_{\text {org }}$ is the mass fraction of organics in particles; $T_{\mathrm{g}, \mathrm{w}}$ is the glass transition temperature of pure water $(136 \mathrm{~K}$; Kohl et al., 2005), and $k_{\mathrm{GT}}$ is the Gordon-Taylor constant for organic-water mixtures which is suggested to be 2.5 ( $\mathrm{Zo}$ brist et al., 2008; Koop et al., 2011). Viscosity can then be calculated by applying the Vogel-Tammann-Fulcher (VTF) equation (Angell, 1991): $\eta=\eta_{\infty} e^{\frac{T_{0} D}{T-T_{0}}}$, where $\eta_{\infty}$ is the viscosity at infinite temperature $\left(10^{-5} \mathrm{~Pa}\right.$ s; Angell, 1991), $D$ is the fragility parameter which is assumed to be 10 (DeRieux et al., 2018), and $T_{0}$ is the Vogel temperature calculated as $T_{0}=\frac{39.17 T_{\mathrm{g}}}{D+39.17}$.

\section{Application in field observations}

\subsection{Southern Oxidant and Aerosol Study (SOAS)}

In this section we predict glass transition temperatures and phase state of ambient OA during the SOAS (Southern Oxidant and Aerosol Study) campaign, which took place in the southeastern United States (Centreville, Alabama) in summer 2013 (Carlton et al., 2018). The $T_{\mathrm{g}}$ of organic aerosols under dry conditions $\left(T_{\mathrm{g}, \text { org }}\right)$ is calculated using Eqs. (1) and (3) with measured volatility distributions. Figure 2 shows the calculated $T_{\mathrm{g}, \text { org }}$ placed in the 2D-VBS framework against the average $\log _{10}\left(C^{*}\right)$ calculated by $\sum_{i} w_{i} \log _{10}\left(C_{i}^{*}\right)$ 


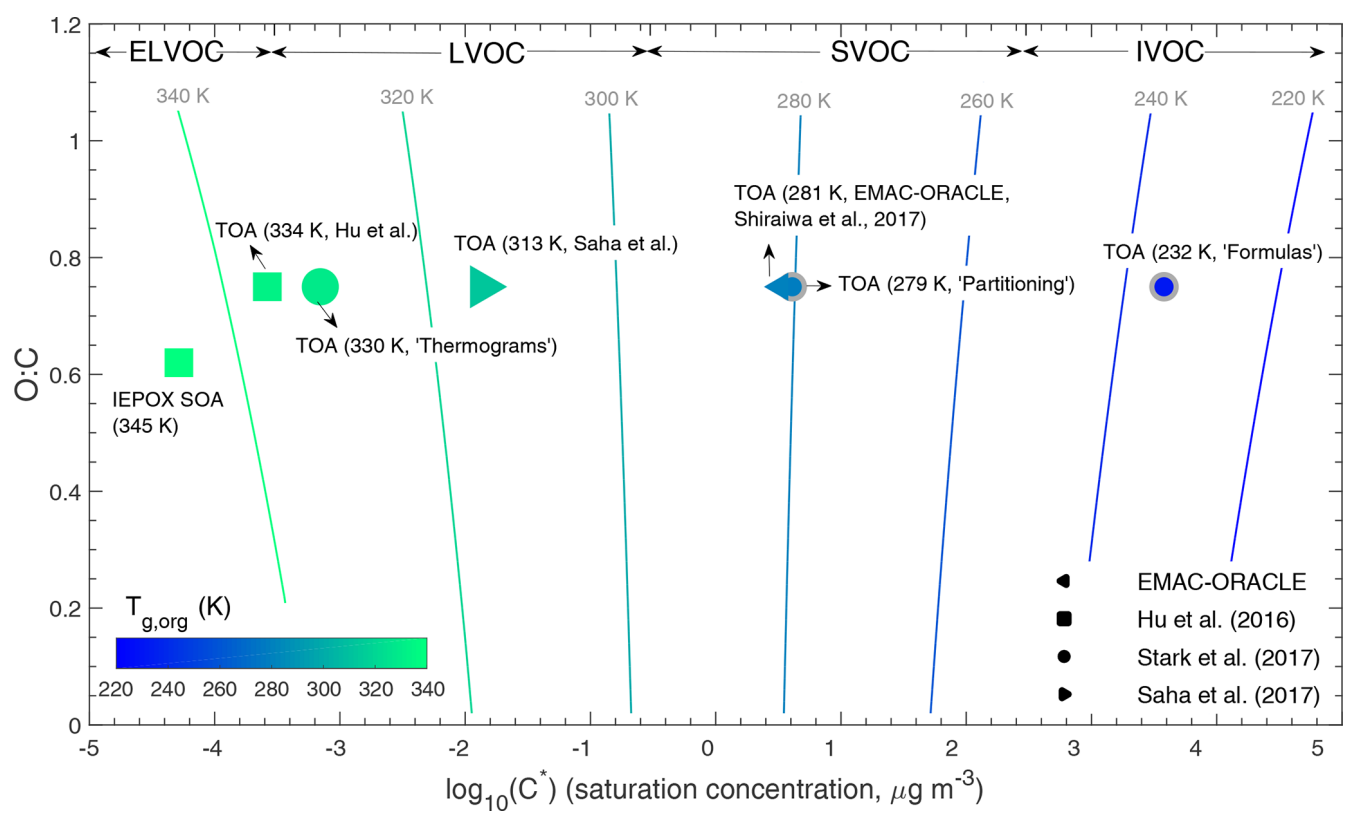

Figure 2. Predicted glass transition temperatures of organic aerosols under dry conditions $\left(T_{\mathrm{g}}, \mathrm{org}\right)$ during the SOAS campaign placed into the 2-D VBS framework. The isopleths correspond to the $T_{\mathrm{g}}$ calculated using Eq. (1) with the effective saturation mass concentration

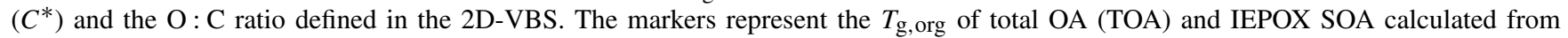
the volatility distributions simulated by a global chemical transport model (EMAC-ORACLE; Shiraiwa et al., 2017) or measured during the SOAS campaign (Hu et al., 2016; Saha et al., 2017; Stark et al., 2017). Three methods (Formulas, Partitioning, and Thermograms) are applied in Stark et al. (2017) to derive the $C^{*}$ distributions, where the Thermograms method provides the most credible volatility distributions compared to Formulas and Partitioning (marker edge lines in gray).

(Kostenidou et al., 2018), and the measured $\mathrm{O}: \mathrm{C}$ ratio is from Xu et al. (2015).

Figure 2 shows that $T_{\mathrm{g}, \text { org }}$ of total OA (TOA) range from 232 to $334 \mathrm{~K}$, depending on volatility distributions measured by different methods, while the most credible predicted $T_{\mathrm{g}, \text { org }}$ values span in the range of $313-330 \mathrm{~K}$. The reasons are stated below by comparing the different methods deriving the $C^{*}$ distributions. Stark et al. (2017) used three methods (Thermograms, Partitioning, and Formulas) to derive volatility distributions by applying the measurements of organic acids (which were shown to account for about half of the total OA; Yatavelli et al., 2015) from a high-resolution chemical ionization time-of-flight mass spectrometer equipped with a filter inlet for gases and aerosols (Lopez-Hilfiker et al., 2014; Thompson et al., 2017). In the Thermograms method, $C^{*}$ at $298 \mathrm{~K}$ is estimated from the desorption temperature after calibration with known species (Faulhaber et al., 2009). This method results in $93 \%$ of OA mass distributed in the LVOC and ELVOC (Stark et al., 2017), and a high $T_{\mathrm{g} \text {,org }}$ of $330 \mathrm{~K}$ is predicted (Fig. 2). While this method may be influenced by thermal decomposition, the peak temperatures of decomposing species can be expected to relate closer to actual volatilities than any of the other two analysis methods (Stark et al., 2017). The result from the thermogram method is consistent with those measured by an aerosol mass spectrometer (AMS) with a thermodenuder, which also applied the thermogram method to estimate the $C^{*}$ distributions (Hu et al., 2016). Saha et al. (2017) applied an evaporation kinetic model (Lee et al., 2011) based on the VBS approach to extract the $C^{*}$ distributions, and the effects of enthalpy of vaporization and accommodation coefficient $(\alpha)$ are considered, resulting in the estimated $T_{\mathrm{g}, \text { org }}$ of $313 \mathrm{~K}$. This study retrieved $\alpha$ of $\sim 0.5$, which is consistent with recent experiments (Krechmer et al., 2017; Liu et al., 2019).

The lower $T_{\mathrm{g}, \text { org }}$ values $(<280 \mathrm{~K})$ calculated from the $C^{*}$ distributions estimated from the Formulas and Partitioning methods (Stark et al., 2017) are less atmospherically relevant. The Formulas method used SIMPOL (simple group contribution method; Pankow and Asher, 2008) to calculate vapor pressures from the composition of the identified ions. While the specific functional group distributions needed for SIMPOL are unknown from mass spectrometer measurements, some assumptions can be made, leading to limits in the volatility distributions, all of which are showing the same behavior of high volatilities (Stark et al., 2017). This is because many of the detected species can be thermal decomposition products rather than actual SOA molecules (Stark et al., 2015, 2017), which can lead to overestimations of volatilities, resulting in the unlikely low $T_{\mathrm{g}, \text { org }}$ of $232 \mathrm{~K}$. The Partitioning method used the measured particle-phase mass fractions of each species to estimate $C^{*}$ based on the partitioning theory (Pankow, 1994). The estimated $C^{*}$ is distributed 
mainly in the SVOC range (Stark et al., 2017), leading to a $T_{\mathrm{g}, \text { org }}$ of $279 \mathrm{~K}$ (Fig. 2). This value is very close to the $T_{\mathrm{g} \text {,org }}$ $(281 \mathrm{~K})$ simulated by a global chemical transport model, EMAC-ORACLE, in which a narrow distribution of $C^{*}(1$,

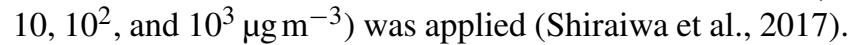
However, Stark et al. (2017) note that the partitioning-based volatility distribution is likely too high due to an artifact of signal-to-noise limitations, confining the $C^{*}$ characterizable by the partitioning method to a relatively narrow range centered around the ambient OA concentration (by definition the semivolatile range). These analyses indicate that the volatility distributions derived from different methods, even when based on the same measurements, significantly affect the predicted $T_{\mathrm{g}, \mathrm{org}}$, and the most atmospherically relevant volatility distributions should be carefully chosen to reasonably predict the glass transition temperature of ambient OA. In summary, the $T_{\mathrm{g}, \text { org }}$ values during the SOAS campaign should be in the range of $313-330 \mathrm{~K}$.

Figure 2 also includes $T_{\mathrm{g} \text {,org }}$ of isoprene-derived epoxydiol SOA (IEPOX-SOA) identified via positive matrix factorization (PMF) of AMS mass spectra (Lanz et al., 2007). IEPOX-SOA is predicted to have a $T_{\mathrm{g}, \text { org }}$ of $345 \mathrm{~K}$ with very low volatility with the average $C^{*}$ lower than $10^{-4} \mu \mathrm{g} \mathrm{m}^{-3}$ (Hu et al., 2016; Lopez-Hilfiker et al., 2016; D'Ambro et al., 2019), which may be due to substantial formation of organosulfates and other oligomers (Lin et al., 2012; Hu et al., 2015; Riva et al., 2019). The predicted $T_{\mathrm{g} \text {,org }}$ of IEPOX-SOA is higher than previously reported $T_{\mathrm{g}, \text { org }}$ of 263-293 K for monoterpene-derived ( $\alpha$-pinene, 3-carene, myrcene, limonene, and ocimene) SOA (Petters et al., 2019).

We further calculate the viscosity of OA based on the $T_{\mathrm{g}, \text { org }}$ of TOA predicted above in order to compare with the ambient phase-state measurements during the SOAS campaign. Figure $3 \mathrm{a}$ shows the predicted viscosity of total OA at different $\mathrm{RH}$; $T$ is adopted as $298 \mathrm{~K}$, the average value during the SOAS campaign (Hu et al., 2016). The effective hygroscopicity parameter $(\kappa)$ is set to 0.14 for TOA based on measurements (Cerully et al., 2015). The characteristic timescale of mass transport and mixing by molecular diffusion $\left(\tau_{\text {mix }}\right)$ is also calculated: $\tau_{\mathrm{mix}}=d_{\mathrm{p}}^{2} /\left(4 \pi^{2} D_{\mathrm{b}}\right)$ (Seinfeld and Pandis, 2006), where $d_{\mathrm{p}}$ is the particle diameter, and the bulk diffusion coefficient $D_{\mathrm{b}}$ is calculated from the predicted viscosity by the fractional Stokes-Einstein relation (Evoy et al., 2019). We assume a radius of the diffusing molecule of $10^{-10} \mathrm{~m}$ and a particle diameter of $200 \mathrm{~nm}$ (Shiraiwa et al., 2011). Note that these estimated timescales represent rough estimations, as molecular interactions in complex mixtures are not considered.

The viscosity of TOA at RH of $83 \%$ (average RH during SOAS) is predicted to be less than $10^{2} \mathrm{Pas}$ with $\tau_{\text {mix }}$ less than $1 \mathrm{~s}$, which is consistent with the particle bounce measurements, suggesting that organic-dominated particles were mostly liquid during the SOAS campaign (Pajunoja et al., 2016). When RH was below $\sim 50 \%$ in the sampling inlet, the particles were found to adopt a semisolid state (Pajunoja et al., 2016), which agrees with the predicted viscosity of $10^{7}-10^{11} \mathrm{Pas}$, and $\tau_{\text {mix }}$ can be higher than $1 \mathrm{~h}$ at $50 \% \mathrm{RH}$ (Fig. 3a). The variations in $T_{\mathrm{g}, \text { org }}(313-330 \mathrm{~K})$ due to the different measured $C^{*}$ distributions (Fig. 2) have a more significant impact on the predicted viscosity at low and medium RH (Fig. 3a). When RH is higher than $\sim 70 \%$, the predicted viscosities calculated from different $T_{\mathrm{g} \text {,org }}$ values are very close; at high RH the condensed-phase water has a larger influence on the phase state than the volatility does, depending on the hygroscopicity of organic aerosols.

Figure $3 \mathrm{~b}$ shows diurnal variations of predicted viscosity of total OA using measured $T$ and RH during the SOAS campaign (Hu et al., 2016). During 10:00-20:00 LT (local time) when $\mathrm{RH}<70 \%$ and $T>298 \mathrm{~K}$, three simulations using different $T_{\mathrm{g}, \text { org }}$ values predict that total OA occurs as semisolid with the predicted viscosity of $10^{2}-10^{7} \mathrm{Pas}$ and the mixing times of less than $1 \mathrm{~h}$. Particles are predicted to have a low viscosity of $<1 \mathrm{~Pa}$, adopting a liquid phase during nighttime. The lowest viscosity occurs around 05:0006:00 LT with RH $>95 \%$. Here we did not consider the effects of the diurnal variations of volatility distributions, as they did not vary dramatically over the campaign period (Saha et al., 2017). Besides $T$ and RH, diurnal variation of ambient aerosol phase state also depends on particle chemical composition and mixing states. Organic particles in the Amazon were found to be more viscous at night than the daytime due to the influence of biomass burning that may form nonliquid particles (Bateman et al., 2017). Particles in a mixed forest in northern Michigan, USA, were also found more viscous at night despite higher RH than the daytime, due to the formation of high molar mass organic compounds and smaller inorganic sulfate mass fractions (Slade et al., 2019). Phase-state measurements during daytime and nighttime at Atlanta, USA, suggested that the ambient particle phase state was influenced by OA composition, the presence of inorganic ions, aerosol liquid water, and particle mixing state (Ditto et al., 2019).

\section{2 $T_{\mathrm{g}, \text { org }}$ at 11 global sites}

Figure 4 summarizes $T_{\mathrm{g}, \text { org }}$ at 11 sites where the measured volatility distributions with volatility bins of four or more are available (Table S3). We did not include the data with narrower volatility ranges which may not correctly characterize the properties of ambient SOA (Bilde et al., 2015), and thus may not be appropriate for estimating volatility distributions or would result in unrealistically low $T_{\mathrm{g}}$ without considering realistically low $C^{*}$ bins. Note that a narrow VBS may still be useful for efficiency in three-dimensional chemical transport models for SOA evaporation and condensation under a narrow range of ambient temperature variations (Kostenidou et al., 2018).

Figure $4 \mathrm{a}$ shows the 2D-VBS framework of $\mathrm{O}: \mathrm{C}$ vs. $\log _{10} C^{*}$ with the marker fill color representing $T_{\mathrm{g}, \text { org }}$, whereas panel (b) shows $T_{\mathrm{g} \text {,org }}$ vs. $\log _{10} C^{*}$ with the marker 
(a)

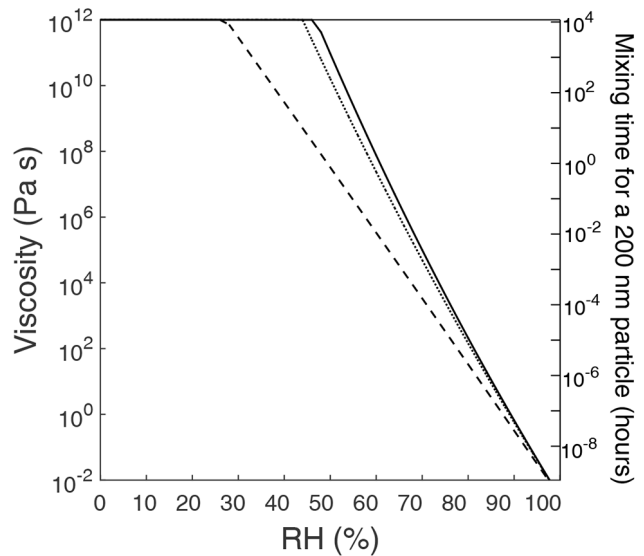

(b)
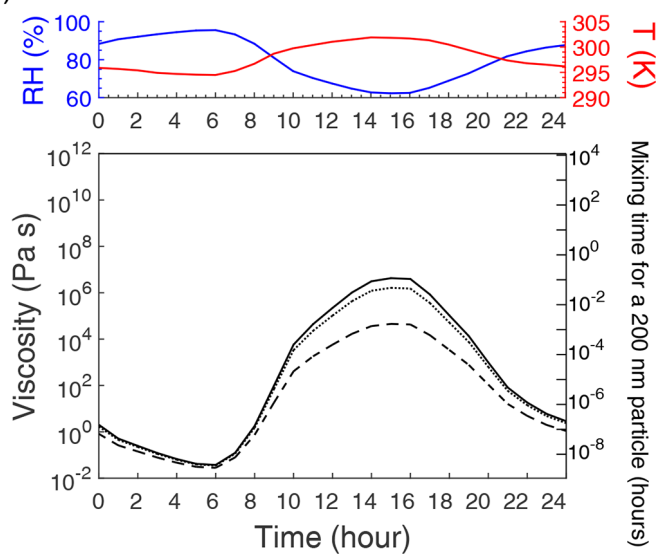

- $\mathrm{T}_{\mathrm{g}, \mathrm{org}}$ predicted by $\mathrm{C}^{*}$ distributions in Hu et al.

.......... $T_{\text {g,org }}$ predicted by $C^{*}$ distributions of "Thermograms" method in Stark et al.

- - $T_{\text {g,org }}$ predicted by $C^{*}$ distributions in Saha et al.

Figure 3. (a) Predicted viscosity of total OA measured during the SOAS campaign as a function of RH. (b) Diurnal variations of viscosity

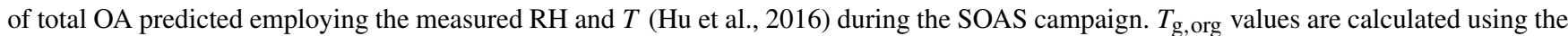
volatility distributions measured in Hu et al. (2016), Saha et al. (2017), and the Thermograms method in Stark et al. (2017). Characteristic mixing timescales of organic molecules with a radius of $10^{-10} \mathrm{~m}$ within $200 \mathrm{~nm}$ particles are also shown on the right axis.

fill color representing $\mathrm{O}: \mathrm{C}$. The marker edge color represents OA components identified via positive matrix factorization of AMS mass spectra (Lanz et al., 2007), including biomass-burning OA (BBOA), hydrocarbon-like OA (HOA), cooking OA (COA), and oxygenated OA (OOA), which is sometimes further separated into more oxygenated OA (MOOOA) and less oxygenated OA (LO-OOA) factors. Note that these different $\mathrm{OA}$ factors may often be internally mixed in ambient atmosphere, and predicted $T_{\mathrm{g}, \text { org }}$ and particle viscosity would be irrelevant in such a case. Nevertheless, these predictions can be useful when particles are externally mixed or ambient OA are dominated by a certain OA factor.

$T_{\mathrm{g}, \text { org }}$ of total OA (TOA) varies from 290 to $339 \mathrm{~K}$. The lower $T_{\mathrm{g}, \text { org }}$ occurs at Beijing, China, in June 2018 (Xu et al., 2019). OA in Beijing was found to be overall more volatile with the particle-phase semivolatile fraction of $63 \%$. This may be due to the higher total OA mass concentrations in Beijing (Xu et al., 2019), which facilitate greater partitioning of SVOC compounds into the particle phase, leading to a lower $T_{\mathrm{g}, \text { org }}$. The predicted $T_{\mathrm{g} \text {,org }}$ of total OA at numerous other sites range between 300 and $320 \mathrm{~K}$, including Paris (Paciga et al., 2016), Mexico City (Cappa and Jimenez, 2010), Centreville (Hu et al., 2016; Saha et al., 2017; Stark et al., 2017), Raleigh (Saha et al., 2017), and Durham (Saha

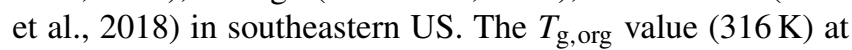
$220 \mathrm{~m}$ downwind from a highway in Durham is higher than the $T_{\mathrm{g}, \text { org }}(309 \mathrm{~K})$ at $10 \mathrm{~m}$ downwind from a highway due to the dilution and mixing of traffic-sourced particles with background air and evaporation of semivolatile species during downwind transport (Saha et al., 2018). The $T_{\mathrm{g}, \text { org }}$ values are predicted to be high $(>320 \mathrm{~K})$ at the sites in Athens
(Louvaris et al., 2017), Pasadena (Ortega et al., 2016), Colorado Rocky Mountain (Stark et al., 2017), and the Amazon (Hu et al., 2016). The $T_{\mathrm{g}, \text { org }}$ values for MO-OOA in Mexico City and Paris are predicted to be very high at $\sim 350 \mathrm{~K}$, reflecting their very low volatility.

Figure 5 shows the OA viscosity variation of OA components against $\mathrm{RH}$. The hygroscopic growth is considered based on hygroscopicity $(\kappa)$, which is estimated as a function of the $\mathrm{O}: \mathrm{C}$ ratio (Lambe et al., 2011) when $\kappa$ was not measured (Table S3). The $\kappa$ values of OA factors with low $\mathrm{O}: \mathrm{C}$ ratio, i.e., $\mathrm{HOA}, \mathrm{COA}$, and $\mathrm{BBOA}$, are estimated to be low $(<0.08)$; they are predicted to undergo glass transition at RH between $25 \%$ and $68 \%$ and adopt a liquid phase only when RH is very high $(\sim 80 \%)$. The predicted behavior of BBOA is in line with bounce measurements observing that particles are semisolid in a biomass-burning plume (Bateman et al., 2017). OA factors with higher $\mathrm{O}: \mathrm{C}$ ratios including LO-OOA, MO-OOA, and IEPOX SOA tend to become liquid (viscosity $<10^{2} \mathrm{Pas}$ ) at intermediate RH (Fig. 5b).

There have been growing measurements of $\mathrm{RH}$-dependent viscosity of laboratory-generated SOA formed from different precursors, e.g., isoprene (Song et al., 2015), $\alpha$-pinene (Abramson et al., 2013; Renbaum-Wolff et al., 2013; Kidd et al., 2014; Pajunoja et al., 2014; Bateman et al., 2015; Zhang et al., 2015; Grayson et al., 2016; Petters et al., 2019), toluene (M. Song et al., 2016), and diesel fuel (Song et al., 2019). As the OOA factors characterized from ambient AMS observations may represent ambient SOA (Jimenez et al., 2009), the predicted viscosities of OOA are compared with laboratory measurements of SOA viscosities in Fig. 5b. It shows that the majority of experimental values is well bounded by 

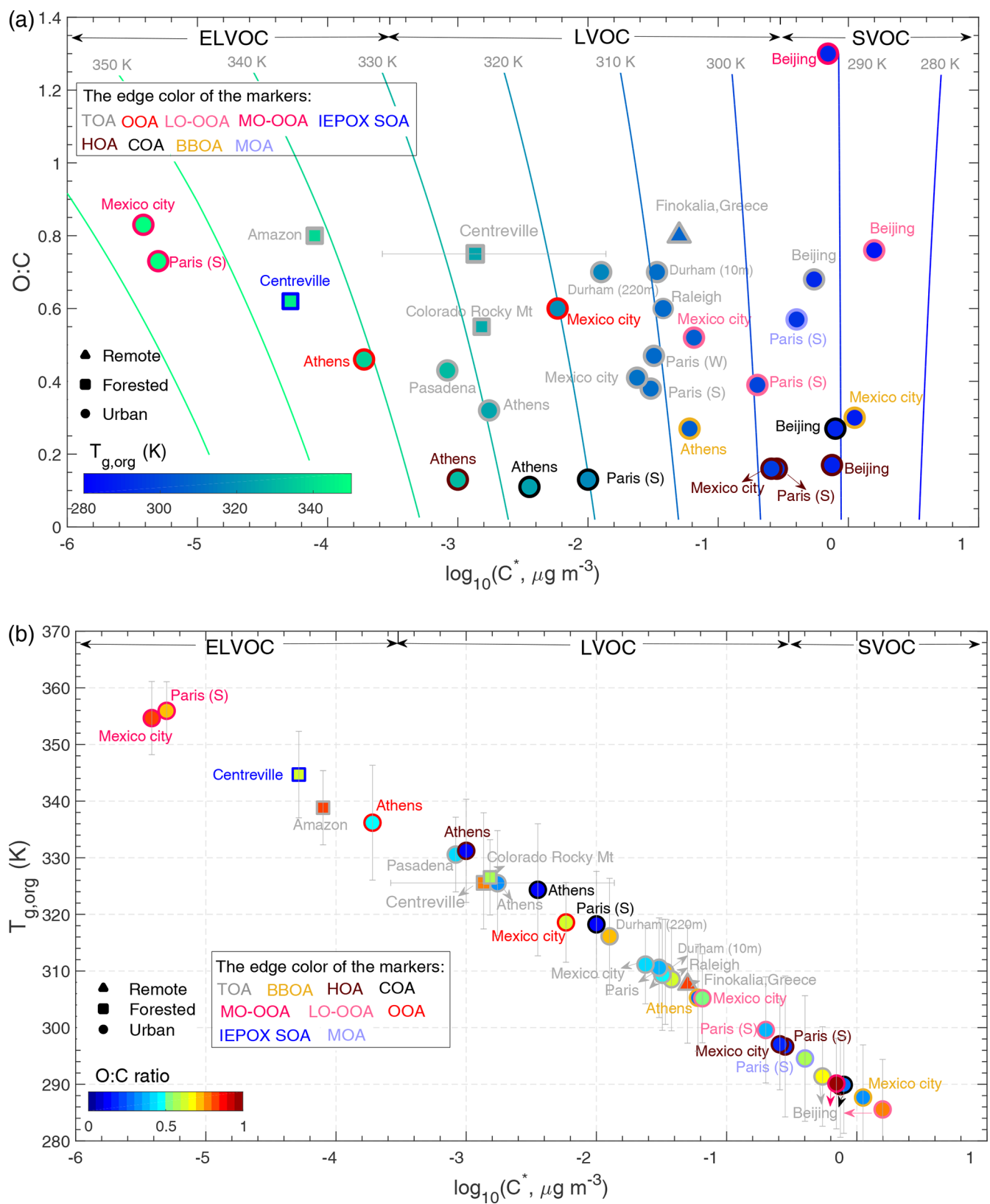

Figure 4. Predicted glass transition temperatures of organic aerosols under dry conditions $\left(T_{\mathrm{g}, \mathrm{org}}\right)$ at 11 sites. The fill color of the markers represents $T_{\mathrm{g}, \text { org }}$ (a) or the $\mathrm{O}: \mathrm{C}$ ratio (b). The marker edge color indicates the OA components identified via PMF of the AMS mass spectra. The isopleths in (a) correspond to $T_{\mathrm{g}}$ calculated using Eq. (1) with $C^{*}$ and $\mathrm{O}: \mathrm{C}$ defined in the 2D-VBS. The vertical error bars correspond to uncertainties in $T_{\mathrm{g} \text {,org }}$ considering parameterization uncertainties and error propagation. The horizontal error bars for the Centreville site correspond to the upper and lower limits of the average $\log _{10}\left(C^{*}\right)$ calculated from different volatility distributions measured during the SOAS campaign (Hu et al., 2016; Saha et al., 2017; Stark et al., 2017).

the predicted viscosities of OOA, represented by the pink shaded area. One exception is the measured viscosity of isoprene SOA is lower than the predicted viscosity of IEPOX SOA at low $\mathrm{RH}(<30 \%)$. One possible reason is that the isoprene $\mathrm{SOA}$ in experiments was formed with high oxidant concentrations with a short reaction time in an oxidation flow reactor in the absence of inorganic seed particles (Song et al., 2015). In ambient environments heterogeneous reactions with acidic sulfate particles forming oligomers are suggested to be an important pathway (Surratt et al., 2010; Lin et al., 2013; Hu et al., 2015, 2016). These particle-phase organosulfates may contribute to a higher viscosity, as indicated by the predicted viscosity of IEPOX-derived organosulfate mixtures with their $T_{\mathrm{g} \text {,org }}$ estimated to be $313 \mathrm{~K}$ (Riva et al., 2019). 

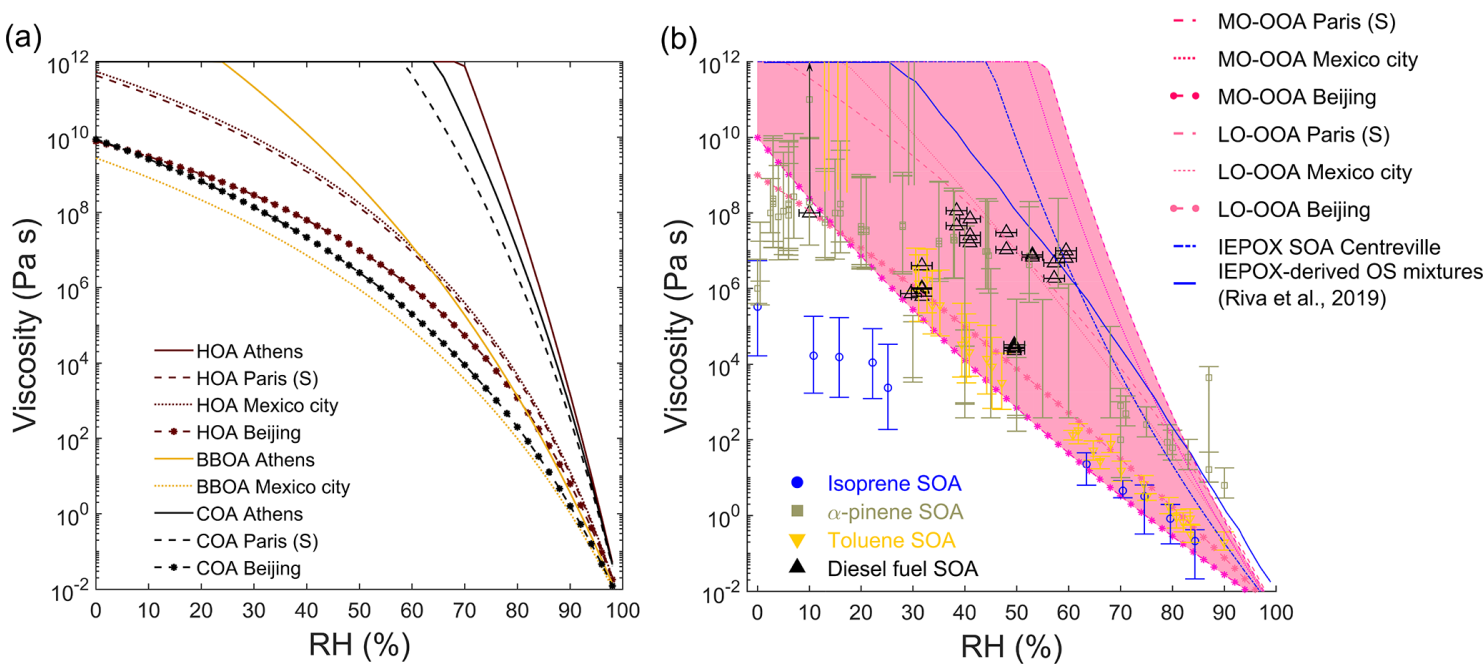

Figure 5. Predicted viscosity of (a) HOA, COA, and BBOA and (b) LO-OOA, MO-OOA, and IEPOX SOA in different locations at 298 K as a function of RH. Experimentally measured viscosity of laboratory-generated SOA formed from isoprene (Song et al., 2015), $\alpha$-pinene (Abramson et al., 2013; Renbaum-Wolff et al., 2013; Kidd et al., 2014; Pajunoja et al., 2014; Bateman et al., 2015; Zhang et al., 2015; Grayson et al., 2016; Petters et al., 2019), toluene (M. Song et al., 2016), and diesel fuel (Song et al., 2019) are also shown. Predicted viscosity of IEPOX-derived OS mixtures (solid blue line) is from Riva et al. (2019). Note that in the case when these OA factors are internally mixed with other components, the predicted viscosity would not represent real ambient complex organic mixtures.

Another reason could be the mass concentrations of isoprene SOA are much higher $\left(100-1000 \mu \mathrm{g} \mathrm{m}^{-3}\right.$; Song et al., 2015) compared to ambient $\mathrm{OA}$ concentrations $\left(5 \mu \mathrm{g} \mathrm{m}{ }^{-3}\right.$ during SOAS; Stark et al., 2017). Higher mass concentrations can lead to lower viscosity, as more semivolatile compounds can partition into the particle phase (Grayson et al., 2016; Jain et al., 2018; Champion et al., 2019).

\section{Comparison with global simulations}

Shiraiwa et al. (2017) simulated the global distribution of annual averages of SOA phase state using the chemical transport model EMAC (Jöckel et al., 2006) coupled with the organic aerosol module ORACLE (Tsimpidi et al., 2014). ORACLE uses the 1D-VBS framework with four $C^{*}$ bins $\left(1,10,10^{2}\right.$, and $\left.10^{3} \mu \mathrm{g} \mathrm{m}^{-3}\right)$. To estimate $T_{\mathrm{g}}$, the values of molar mass and $\mathrm{O}: \mathrm{C}$ ratio were assigned for each volatility bin based on molecular corridors (Shiraiwa et al., 2014). Note that the molar mass assigned for the volatility bin of $1 \mu \mathrm{g} \mathrm{m}^{-3}$ was assumed to have relatively high molar mass to partially compensate for the fact that ORACLE does not consider lower volatility bins with higher molar mass. As shown in Fig. 6, global distributions of $T_{\mathrm{g}} / T$ presented in Shiraiwa et al. (2017) are converted to viscosity using the VTF equation. Figure 6 also includes the viscosity of total $\mathrm{OA}$ at the 11 sites by applying measured volatility distributions and the global model-simulated 5-year-average $T$ and RH with $\kappa$ assumed to be 0.1 (Pringle et al., 2010). Figure 6b shows that the predicted viscosities at the 11 sites generally agree with the global simulations: the amorphous solid or semisolid phase occurs over relatively dry areas, including the sites in western US, Mexico City, Beijing, and coastal sites in Greece; the lower viscosity occurs in southeastern US and Paris.

The global simulations show that the particles are liquid in the Amazon, while they occur as semisolid in our predictions based on measured volatility distributions (Fig. 6a). The reason for this disagreement may be mainly due to the substantial fraction of low volatility compounds observed in ambient measurements largely missing from global simulations. $\mathrm{Hu}$ et al. (2016) observed that $90 \%$ of OA has volatilities lower than $1 \mu \mathrm{g} \mathrm{m}^{-3}$, which is the lowest $C^{*}$ bin in the global simulations. The ambient phase-state measurements show that for background conditions of the Amazonian tropical forest particles are mostly liquid, while for the anthropogenic influence including both urban pollution and biomass burning they occur as semisolid or glassy (Bateman et al., 2016, 2017). The volatility distributions were measured in the dry season that is heavily influenced by biomass burning ( $\mathrm{Hu}$ et al., 2016), which can lead to the higher predicted viscosity. Similar cases are observed in Athens and the two sites in the western US, that our predictions based on volatility distributions indicate the glassy phase state, while the global model predicts the occurrence of a semisolid phase.

\section{Conclusions and implications}

We have developed parameterizations to estimate the glass transition temperature of organic compounds using saturation mass concentration $\left(C^{0}\right)$ and atomic $\mathrm{O}: \mathrm{C}$ ratio. They 
(a)

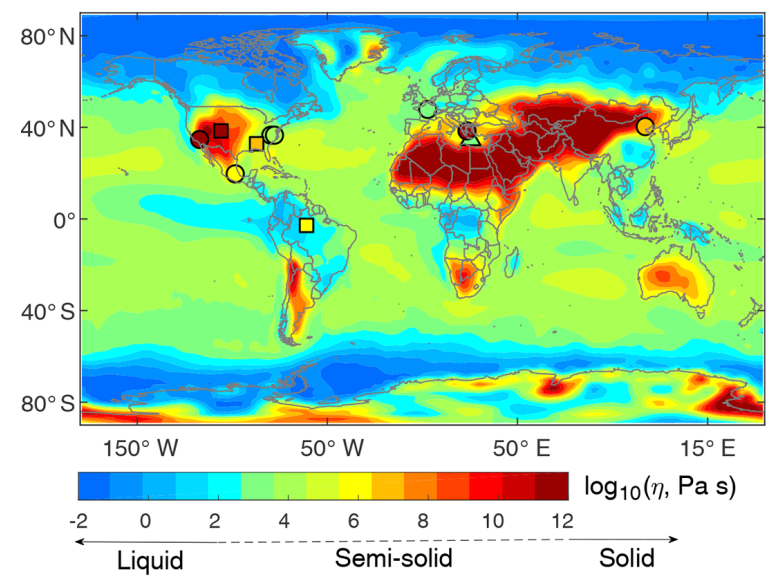

(b)

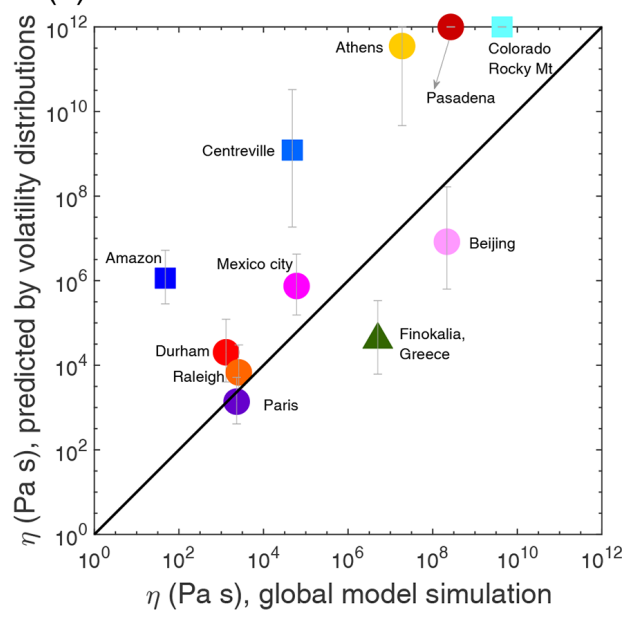

Figure 6. (a) Global distributions of SOA annually averaged viscosity at the surface simulated by a global chemical transport model (Shiraiwa et al., 2017) with the viscosity predicted by measured volatility distributions at 11 global sites (triangle, square, and circle represent remote, forested, and urban sites, respectively, Table S3). The color code indicates viscosity on a log scale. (b) Predicted viscosity based on measured volatility distributions compared against the viscosity in global simulations. The error bars correspond to uncertainties in viscosities calculated from uncertainties in predicted $T_{\mathrm{g} \text {, org }}$ shown in Fig. 4.

can be applied to ambient observations of volatility distributions to estimate viscosity of ambient organic aerosols. The $T_{\mathrm{g}}$ and viscosity prediction method can be applied in the volatility basis set or the molecular-corridor-based approach to improve OA simulations in chemical transport models by consideration of effects of particle viscosity on OA formation and evolution (Shiraiwa et al., 2017; Pye et al., 2017; Schmedding et al., 2019). Most of the current chemical transport models treat particles as a homogeneously well-mixed liquid without considering particle-phase diffusion limitations, which can lead to bias in simulations of SOA mass concentrations and evolution of size distributions (Shiraiwa and Seinfeld, 2012; Zaveri et al., 2018). The SOA simulations applying the VBS framework have not yet included the effects of viscosity on SOA formation and evolution. When the gasparticle partitioning is limited by bulk diffusion, kinetic treatments of SOA partitioning may need to be applied (Perraud et al., 2012; Liu et al., 2016; Yli-Juuti et al., 2017; Li and Shiraiwa, 2019). Some chamber experiments probing the mixing timescales of SOA particles formed from isoprene, $\alpha$-pinene, and limonene did not observe significant kinetic limitations at moderate and high $\mathrm{RH}$ under room temperature conditions (Loza et al., 2013; Ye et al., 2016), while kinetic limitations of bulk diffusion of organic molecules in $\beta$-caryophyllene SOA have been observed at $75 \%$ RH (Ye et al., 2018), warranting further investigations on the degree of kinetic limitations in ambient tropospheric conditions. In addition, the interplay of diffusion limitations and phase separation impacts heterogeneous and multiphase chemistry (Vander Wall et al., 2018; DeRieux et al., 2019; Zhou et al., 2019) and gasparticle partitioning (Zuend and Seinfeld, 2012; Shiraiwa et al., 2013; Freedman, 2017; Pye et al., 2017; Gorkowski et al., 2019a). The particle morphology and the degree of nonideal mixing and liquid-liquid phase separation can evolve upon atmospheric aging (Gorkowski et al., 2019b). These aspects may also need to be considered for better representation of organic aerosols in future studies. 


\section{Appendix A: Parameterizations of $T_{\mathrm{g}}$ based on elemental compositions}

We recently developed a parameterization (Eq. A1) predicting $T_{\mathrm{g}}$ as a function of the number of carbon $\left(n_{\mathrm{C}}\right)$, hydrogen $\left(n_{\mathrm{H}}\right)$, and oxygen $\left(n_{\mathrm{O}}\right)$ atoms (DeRieux et al., 2018), similar to the formulation used to predict $C^{0}$ (Donahue et al., 2011; Li et al., 2016):

$$
\begin{aligned}
T_{\mathrm{g}}= & \left(n_{\mathrm{C}}^{0}+\ln \left(n_{\mathrm{C}}\right)\right) b_{\mathrm{C}}+\ln \left(n_{\mathrm{H}}\right) b_{\mathrm{H}}+\ln \left(n_{\mathrm{C}}\right) \ln \left(n_{\mathrm{H}}\right) b_{\mathrm{CH}} \\
& +\ln \left(n_{\mathrm{O}}\right) b_{\mathrm{O}}+\ln \left(n_{\mathrm{C}}\right) \ln \left(n_{\mathrm{O}}\right) b_{\mathrm{CO}} .
\end{aligned}
$$

Values of the coefficients $n_{\mathrm{C}}^{0}, b_{\mathrm{C}}, b_{\mathrm{H}}, b_{\mathrm{CH}}, b_{\mathrm{O}}$, and $b_{\mathrm{CO}}$ are $1.96,61.99,-113.33,28.74,0$, and 0 for $\mathrm{CH}$ compounds and $12.13,10.95,-41.82,21.61,118.96$, and -24.38 for $\mathrm{CHO}$ compounds. We broaden the parameterizations for $\mathrm{CH}$ and $\mathrm{CHO}$ compounds (Eq. A1) to the following equations applicable to CHON (Eq. A2) and CHOS compounds (Eq. A3):

$$
\begin{aligned}
T_{\mathrm{g}}= & \left(n_{\mathrm{C}}^{0}+\ln \left(n_{\mathrm{C}}\right)\right) b_{\mathrm{C}}+\ln \left(n_{\mathrm{O}}\right) b_{\mathrm{O}}+\ln \left(n_{\mathrm{N}}\right) b_{\mathrm{N}} \\
& +\ln \left(n_{\mathrm{C}}\right) \ln \left(n_{\mathrm{O}}\right) b_{\mathrm{CO}}+\ln \left(n_{\mathrm{C}}\right) \ln \left(n_{\mathrm{N}}\right) b_{\mathrm{CN}} \\
& +\ln \left(n_{\mathrm{O}}\right) \ln \left(n_{\mathrm{N}}\right) b_{\mathrm{ON}} \\
T_{\mathrm{g}}= & \left(n_{\mathrm{C}}^{0}+\ln \left(n_{\mathrm{C}}\right)\right) b_{\mathrm{C}}+\ln \left(n_{\mathrm{O}}\right) b_{\mathrm{O}}+\ln \left(n_{\mathrm{S}}\right) b_{\mathrm{S}} \\
& +\ln \left(n_{\mathrm{C}}\right) \ln \left(n_{\mathrm{O}}\right) b_{\mathrm{CO}}+\ln \left(n_{\mathrm{C}}\right) \ln \left(n_{\mathrm{S}}\right) b_{\mathrm{CS}} \\
& +\ln \left(n_{\mathrm{O}}\right) \ln \left(n_{\mathrm{S}}\right) b_{\mathrm{OS}} .
\end{aligned}
$$

Values of the coefficients $n_{\mathrm{C}}^{0}, b_{\mathrm{C}}, b_{\mathrm{O}}, b_{\mathrm{N}}, b_{\mathrm{CO}}, b_{\mathrm{CN}}$, and $b_{\mathrm{ON}}$ in Eq. (A2) are 5.34, 31.53, -7.06, 134.96, 6.54, -34.36, and -15.35 , respectively. Values of the coefficients $n_{\mathrm{C}}^{0}, b_{\mathrm{C}}$, $b_{\mathrm{O}}, b_{\mathrm{S}}, b_{\mathrm{CO}}, b_{\mathrm{CS}}$, and $b_{\mathrm{OS}}$ in Eq. (A3) are 1.12, 68.41, 64.95, $35.77,-12.32,-9.85$, and 13.80 , respectively. These values are obtained by fitting the $T_{\mathrm{g}}$ of CHON and CHOS compounds included in the training dataset (Fig. 1a, Table S1) with multilinear least squares analysis. Figure A1a shows a fair agreement between the predicted $T_{\mathrm{g}}$ using Eq. (A2) and the measured or otherwise estimated $T_{\mathrm{g}}$ with $R$ of 0.55 and relatively large AAVRE of $16 \%$ for $\mathrm{CHON}$ compounds in the training dataset. Figure A1b shows a better prediction performance with $R$ of 0.83 and AAVRE of $9 \%$ for $212 \mathrm{CHON}$ compounds included in the test dataset for SOA components with their $T_{\mathrm{g}}$ estimated by the Boyer-Kauzmann rule using the EPI-estimated $T_{\mathrm{m}}$. Figure A1c shows that Eq. (A3) performs well for the CHOS compounds included in the training dataset with their $T_{\mathrm{g}}$ estimated by the Boyer-Kauzmann rule using the EPI-estimated $T_{\mathrm{m}}(R=0.87$, AAVRE $=8 \%)$.

Figure S5 shows the comparison of $T_{\mathrm{g}}$ predicted by the elemental composition (Eqs. A1-A3) with the $T_{\mathrm{g}}$ predicted as a function of $C^{0}$ and the $\mathrm{O}: \mathrm{C}$ ratio (Eq. 1). The agreement between the two sets of parameterizations for nitrogenand sulfur-containing compounds is not as good as that for $\mathrm{CHO}$ compounds, indicating that there are limitations of predicting $T_{\mathrm{g}}$ by the elemental composition for nitrogen- and sulfur-containing compounds with complex elemental compositions and molecular structures. As volatility depends significantly on functional groups contained in a molecule (Pankow and Asher, 2008; Compernolle et al., 2011), predicting $T_{\mathrm{g}}$ by volatility (Eq. 1) indirectly incorporates the molecular structure effects. As there are limited CHON and CHOS compounds with measured $T_{\mathrm{g}}$ available, future experiments measuring more $T_{\mathrm{g}}$ data for nitrogen- and sulfurcontaining organics would help improve the $T_{\mathrm{g}}$ parameterizations by elemental composition.

\section{Appendix B: Comparison of $T_{\mathrm{g}}$ predictions with Zhang et al. (2019)}

Recently Zhang et al. (2019) developed a semiempirical parameterization (Eq. B1) using vapor pressure ( $p_{0}$ in atm) to predict $T_{\mathrm{g}}$ based on measured $T_{\mathrm{g}}$ of 11 SOA compounds:

$$
T_{\mathrm{g}}=480.1-\frac{54395}{\left(\log _{10}\left(p_{0}\right)-1.7929\right)^{2}+116.49} .
$$

$p_{0}$ can be converted to $C^{0}$ via $C^{0}=\left(10^{6} M p_{0}\right) /(R T)$, where $R$ is the ideal gas constant $(R=8.2 \times$ $10^{-5} \mathrm{~m}^{3}$ atm mol$\left.{ }^{-1} \mathrm{~K}^{-1}\right), M$ is the molar mass $\left(\mathrm{g} \mathrm{mol}^{-1}\right)$, and $T$ is the temperature $(\mathrm{K})$. Figure B1 compares the measured $T_{\mathrm{g}}$ included in the training dataset shown in Fig. 1a to $T_{\mathrm{g}}$ predicted by (a) $C^{0}$ and the atomic $\mathrm{O}: \mathrm{C}$ ratio (Eq. 1), (b) elemental composition (Eqs. A1-A3), and (c) Eq. (B1) by Zhang et al. (2019). While all three methods perform reasonably well, the predictions using elemental composition (Eqs. A1-A3) show better performance (Fig. B1b) with $R$ of 0.93 and AAVRE of $11 \%$.

The prediction performance is influenced by the training dataset used to develop parameterizations of $T_{\mathrm{g}}$. The compounds shown in Fig. B1 contain mostly carboxylic acid and hydroxyl functional groups (Koop et al., 2011; Rothfuss and Petters, 2017) and are included in the training dataset used to develop Eqs. (1) and Eqs. (A1)-(A3). The training dataset used in Zhang et al. (2019) included 11 organic compounds, and their parameterization predicted $T_{\mathrm{g}}$ of isoprene SOA very well (Zhang et al., 2019), but underpredicted some low- $T_{\mathrm{g}}$ compounds (Fig. B1c). For compounds with their measured $T_{\mathrm{g}}$ higher than $200 \mathrm{~K}$, predictions by Zhang et al. (2019) show good performance and are consistent with the predictions given by Eq. (1) as a function of $C^{0}$ and the $\mathrm{O}: \mathrm{C}$ ratio. Predicted $T_{\mathrm{g}}$ values of 2 -MT-OS using the three methods are $297 \mathrm{~K}$ (Eq. 1, as a function of $C^{0}$ and the $\mathrm{O}: \mathrm{C}$ ratio), $275 \mathrm{~K}$ (Eq. A3, as a function of the elemental composition), and $280 \mathrm{~K}$ (Eq. B1, Zhang et al., 2019), comparable with the measured $T_{\mathrm{g}}$ of $276 \pm 15 \mathrm{~K}$ (Zhang et al., 2019).

Note that predictions using elemental composition (Eq. A1) overestimate the $T_{\mathrm{g}}$ of phthalate compounds (the star markers in Fig. B1). For instance, the observed $T_{\mathrm{g}}$ of dioctyl phthalate is $194 \mathrm{~K}$ (Zhang et al., 2018), while the prediction is higher than $300 \mathrm{~K}$ (Fig. B1b). The reason is that ester is not an effective functional group to increase viscosity compared to carboxylic acid and hydroxyl (Rothfuss 
(a) CHON compounds in the training datset shown in Fig. 1a

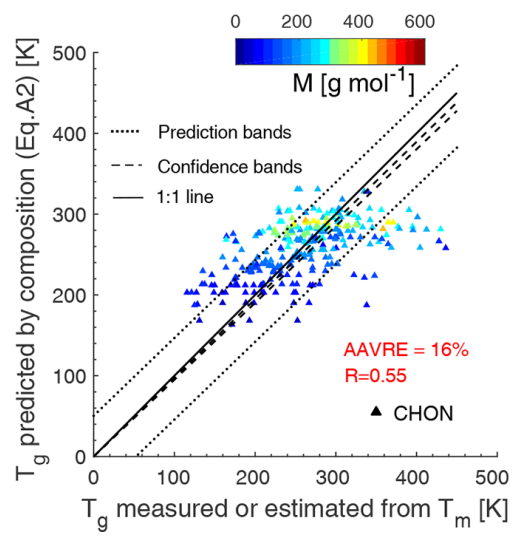

(b) CHON compounds in the test datset for SOA components shown in Fig. 1C

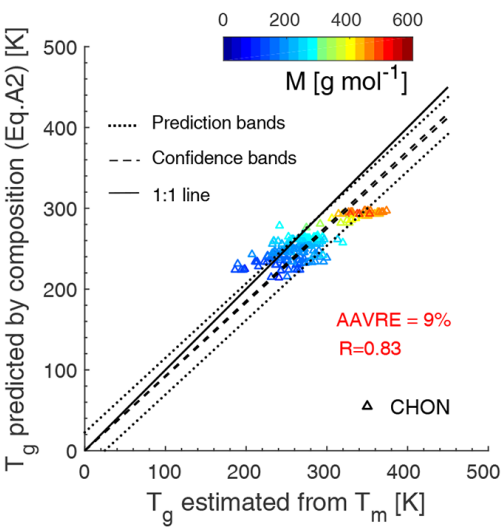

(c) $\mathrm{CHOS}$ compounds in the training datset shown in Fig. 1 a

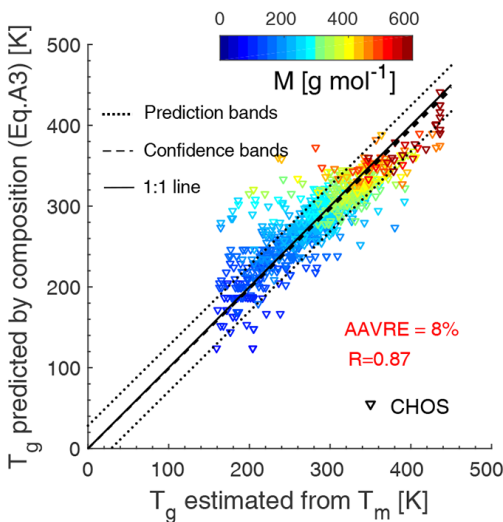

Figure A1. $T_{\mathrm{g}}$ predicted by elemental composition (Eq. A2) compared to (a) measured or otherwise estimated $T_{\mathrm{g}}$ by the Boyer-Kauzmann rule using measured $T_{\mathrm{m}}$ for $\mathrm{CHON}$ compounds in the training dataset and (b) estimated $T_{\mathrm{g}}$ by the Boyer-Kauzmann rule with $T_{\mathrm{m}}$ estimated by the EPI Suite for CHON compounds in the test dataset for SOA components. (c) $T_{\mathrm{g}}$ predicted by elemental composition (Eq. A3) compared to estimated $T_{\mathrm{g}}$ by the Boyer-Kauzmann rule with $T_{\mathrm{m}}$ estimated by the EPI Suite for CHOS compounds in the training dataset. The dashed and dotted lines show $68 \%$ confidence and prediction bands, respectively. The correlation coefficient $(R)$ and the average absolute value of the relative error (AAVRE) are included in each figure legend.
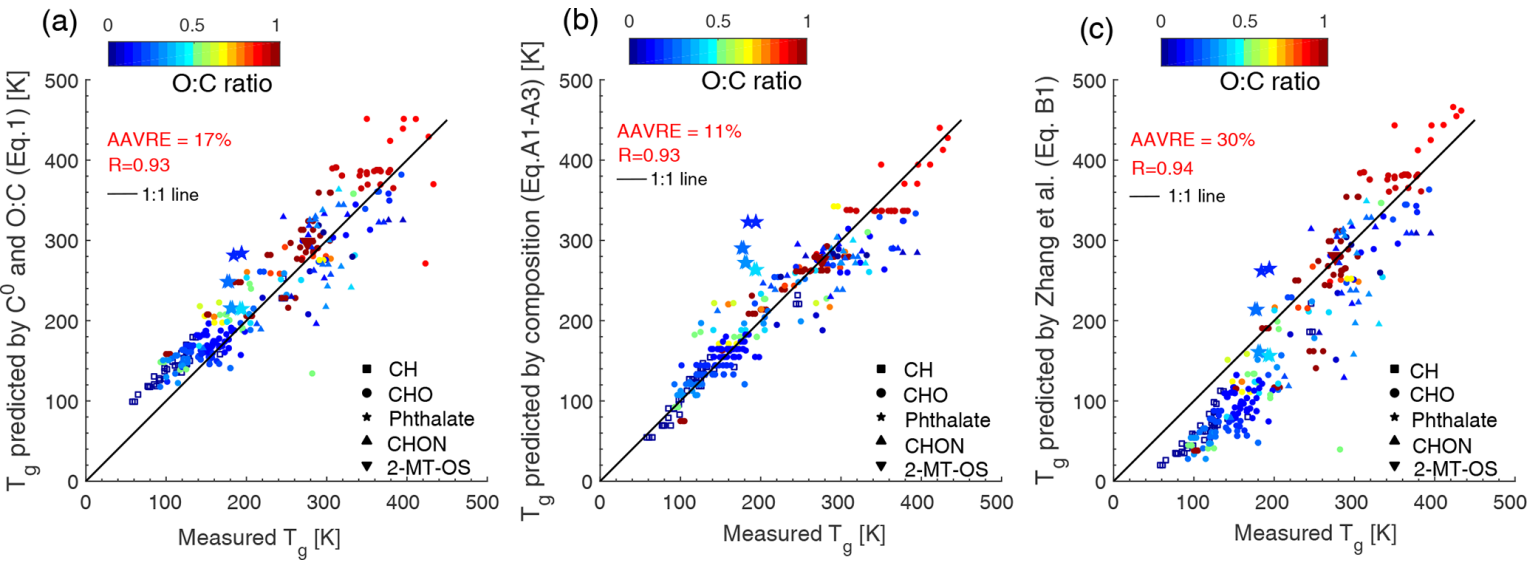

Figure B1. Comparison between measured $T_{\mathrm{g}}$ in the training dataset in Fig. 1a and $T_{\mathrm{g}}$ predicted by (a) $C^{0}$ and $\mathrm{O}: \mathrm{C}$ (Eq. 1 ), (b) elemental composition (Eqs. A1-A3), and (c) the parameterization (Eq. B1) in Zhang et al. (2019). The solid line shows the $1: 1$ line. The correlation coefficient $(R)$ and the average absolute value of the relative error (AAVRE) are included in each figure legend.

and Petters, 2017). Parameterizations using volatility (Eqs. 1 and B1) improve the predicted $T_{\mathrm{g}}$ of phthalate compounds (Fig. B1a, c). Figure B2 shows, compared to the predictions using Eq. (B1) provided in Zhang et al. (2019), that predictions by $C^{0}$ and the atomic $\mathrm{O}: \mathrm{C}$ (Eq. 1) and elemental composition (Eq. A1) agree better with the $T_{\mathrm{g}}$ estimated from the Boyer-Kauzmann rule. Future experiments measuring more $T_{\mathrm{g}}$ data of SOA components would help verify the $T_{\mathrm{g}}$ predictions by different parameterizations. 

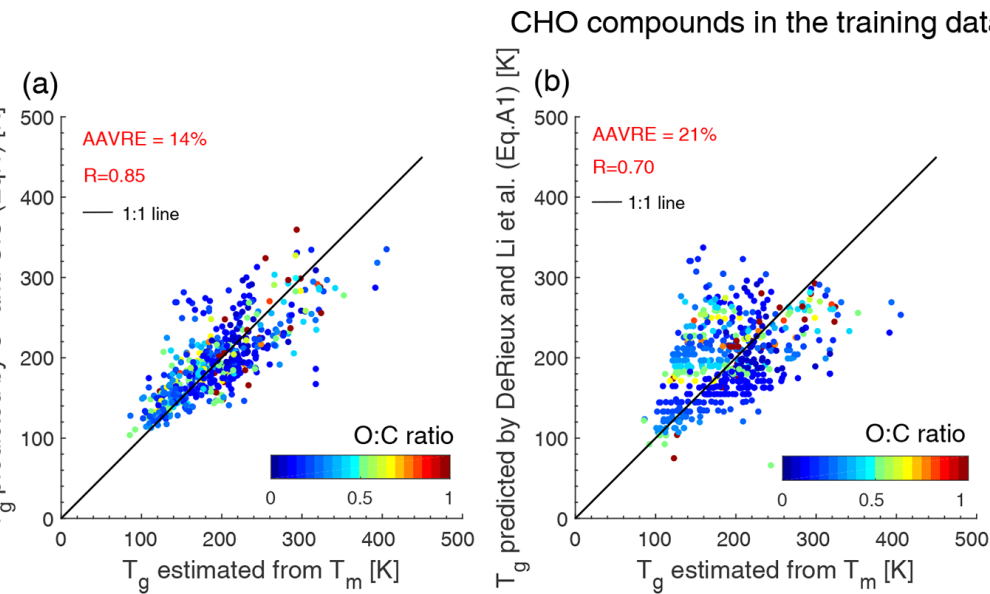

(c)

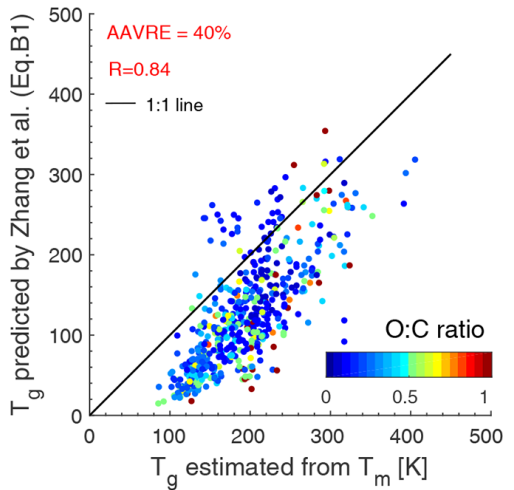

$\mathrm{CHO}$ compounds in the test dataset for SOA components

(d)

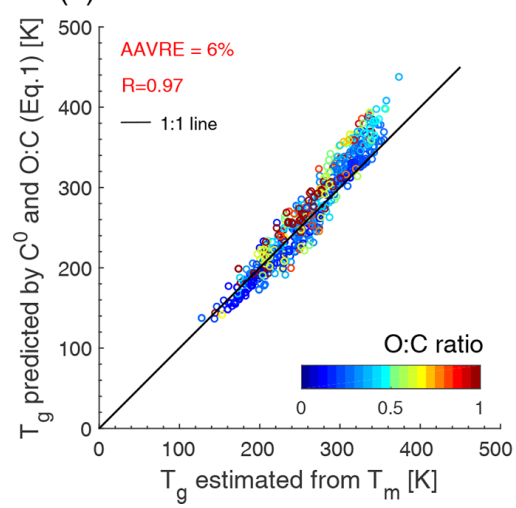

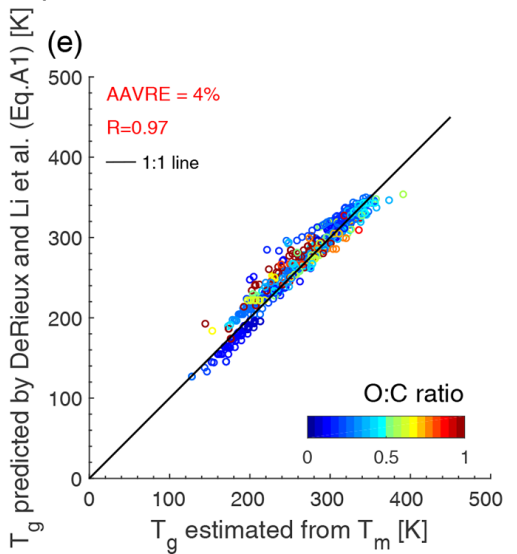

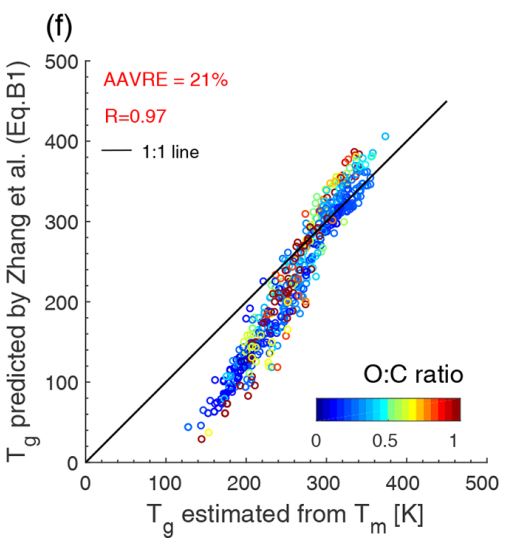

Figure B2. Predicted $T_{\mathrm{g}}$ by (a) $C^{0}$ and $\mathrm{O}: \mathrm{C}$ (Eq. 1), (b) elemental composition (Eq. A1), and (c) the parameterization (Eq. B1) in Zhang et al. (2019) plotted against estimated $T_{\mathrm{g}}$ from $T_{\mathrm{m}}$ applying the Boyer-Kauzmann rule. CHO compounds in (a)-(c) included in the training dataset shown in Fig. 1a are with measured $T_{\mathrm{m}}$ and $C^{0}$ values; $\mathrm{CHO}$ compounds in (d)-(f) included in the test dataset for SOA components shown in Fig. 1c are with $T_{\mathrm{m}}$ and $C^{0}$ values estimated by the EPI Suite and the EVAPORATION model, respectively. The correlation coefficient $(R)$ and the average absolute value of the relative error (AAVRE) are shown. 
Data availability. The data used in this study are available in the Supplement.

Supplement. The supplement related to this article is available online at: https://doi.org/10.5194/acp-20-8103-2020-supplement.

Author contributions. YL, JLJ, and MS designed the research. YL developed the parameterizations. DAD, HS, and JLJ provided measured volatility distributions for the SOAS campaign. YL and MS wrote the article. All authors discussed the results and contributed to article editing.

Acknowledgements. We thank Alexandra Tsimpidi, Vlassis Karydis, Spyros Pandis, and Jos Lelieveld for global simulations of SOA concentrations used to calculate $T_{\mathrm{g}} / T$ (as presented in Shiraiwa et al., 2017), which are converted into viscosity (Fig. 6). We also thank Sergey Nizkorodov, Andreas Zuend, Yue Zhang, Jason Surratt, and Markus Petters for stimulating discussions.

Financial support. This research has been supported by the National Science Foundation, Division of Atmospheric and Geospace Sciences (grant nos. AGS-1654104 and AGS-1822664) and the U.S. Department of Energy (grant nos. DE-SC0018349 and DESC0016559).

Review statement. This paper was edited by Neil M. Donahue and reviewed by two anonymous referees.

\section{References}

Abramson, E., Imre, D., Beranek, J., Wilson, J. M., and Zelenyuk, A.: Experimental determination of chemical diffusion within secondary organic aerosol particles, Phys. Chem. Chem. Phys., 15, 2983-2991, https://doi.org/10.1039/c2cp44013j, 2013.

Aiken, A. C., DeCarlo, P. F., and Jimenez, J. L.: Elemental analysis of organic species with electron ionization highresolution mass spectrometry, Anal. Chem., 79, 8350-8358, https://doi.org/10.1021/ac071150w, 2007.

Angell, C.: Relaxation in liquids, polymers and plastic crystals - strong/fragile patterns and problems, J. Non-Cryst. Solids, 131-133, 13-31, https://doi.org/10.1016/0022-3093(91)902669, 1991.

Bateman, A. P., Bertram, A. K., and Martin, S. T.: Hygroscopic influence on the semisolid-to-liquid transition of secondary organic materials, J. Phys. Chem. A, 119, 4386-4395, https://doi.org/10.1021/jp508521c, 2015.

Bateman, A. P., Gong, Z., Liu, P., Sato, B., Cirino, G., Zhang, Y., Artaxo, P., Bertram, A. K., Manzi, A. O., Rizzo, L. V., Souza, R. A. F., Zaveri, R. A., and Martin, S. T.: Sub-micrometre particulate matter is primarily in liquid form over Amazon rainforest, Nat. Geosci., 9, 34-37, https://doi.org/10.1038/ngeo2599, 2016.
Bateman, A. P., Gong, Z., Harder, T. H., de Sá, S. S., Wang, B., Castillo, P., China, S., Liu, Y., O’Brien, R. E., Palm, B. B., Shiu, H.-W., Cirino, G. G., Thalman, R., Adachi, K., Alexander, M. L., Artaxo, P., Bertram, A. K., Buseck, P. R., Gilles, M. K., Jimenez, J. L., Laskin, A., Manzi, A. O., Sedlacek, A., Souza, R. A. F., Wang, J., Zaveri, R., and Martin, S. T.: Anthropogenic influences on the physical state of submicron particulate matter over a tropical forest, Atmos. Chem. Phys., 17, 1759-1773, https://doi.org/10.5194/acp-17-1759-2017, 2017.

Berkemeier, T., Shiraiwa, M., Pöschl, U., and Koop, T.: Competition between water uptake and ice nucleation by glassy organic aerosol particles, Atmos. Chem. Phys., 14, 12513-12531, https://doi.org/10.5194/acp-14-12513-2014, 2014.

Bilde, M., Barsanti, K., Booth, M., Cappa, C. D., Donahue, N. M., Emanuelsson, E. U., McFiggans, G., Krieger, U. K., Marcolli, C., Topping, D., Ziemann, P., Barley, M., Clegg, S., Dennis-Smither, B., Hallquist, M., Hallquist, Å. M., Khlystov, A., Kulmala, M., Mogensen, D., Percival, C. J., Pope, F., Reid, J. P., Ribeiro da Silva, M. A. V., Rosenoern, T., Salo, K., Soonsin, V. P., Yli-Juuti, T., Prisle, N. L., Pagels, J., Rarey, J., Zardini, A. A., and Riipinen, I.: Saturation vapor pressures and transition enthalpies of low-volatility organic molecules of atmospheric relevance: from dicarboxylic acids to complex mixtures, Chem. Rev., 115, 41154156, https://doi.org/10.1021/cr5005502, 2015.

Bosse, D.: Diffusion, viscosity, and thermodynamics in liquid systems, $\mathrm{PhD}$ thesis, available at: https://kluedo.ub.uni-kl.de/ frontdoor/deliver/index/docId/1691/file/PhD-Bosse-published. pdf (last access: 9 July 2020), 2005.

Boyer, R. F.: Relationship of first-to second-order transition temperatures for crystalline high polymers, J. Appl. Phys., 25, 825-829, https://doi.org/10.1063/1.1721752, 1954.

Cao, W., Knudsen, K., Fredenslund, A. and Rasmussen, P.: Group-contribution viscosity predictions of liquid mixtures using UNIFAC-VLE parameters, Ind. Eng. Chem. Res., 32, 2088 2092, https://doi.org/10.1021/ie00021a034, 1993.

Capouet, M. and Müller, J.-F.: A group contribution method for estimating the vapour pressures of $\alpha$-pinene oxidation products, Atmos. Chem. Phys., 6, 1455-1467, https://doi.org/10.5194/acp-61455-2006, 2006.

Cappa, C. D. and Jimenez, J. L.: Quantitative estimates of the volatility of ambient organic aerosol, Atmos. Chem. Phys., 10, 5409-5424, https://doi.org/10.5194/acp-10-5409-2010, 2010.

Carlton, A. G., de Gouw, J., Jimenez, J. L., Ambrose, J. L., Attwood, A. R., Brown, S., Baker, K. R., Brock, C., Cohen, R. C., and Edgerton, S.: Synthesis of the southeast atmosphere studies: Investigating fundamental atmospheric chemistry questions, B. Am. Meteorol. Soc., 99, 547-567, https://doi.org/10.1175/BAMS-D-16-0048.1, 2018.

Cerully, K. M., Bougiatioti, A., Hite Jr., J. R., Guo, H., Xu, L., Ng, N. L., Weber, R., and Nenes, A.: On the link between hygroscopicity, volatility, and oxidation state of ambient and water-soluble aerosols in the southeastern United States, Atmos. Chem. Phys., 15, 8679-8694, https://doi.org/10.5194/acp15-8679-2015, 2015.

Champion, W. M., Rothfuss, N. E., Petters, M. D., and Grieshop, A. P.: Volatility and viscosity are correlated in terpene secondary organic aerosol formed in a flow reactor, Environ. Sci. Tech. Let., 6, 513-519, https://doi.org/10.1021/acs.estlett.9b00412, 2019. 
Chenyakin, Y., Ullmann, D. A., Evoy, E., Renbaum-Wolff, L., Kamal, S., and Bertram, A. K.: Diffusion coefficients of organic molecules in sucrose-water solutions and comparison with Stokes-Einstein predictions, Atmos. Chem. Phys., 17, 24232435, https://doi.org/10.5194/acp-17-2423-2017, 2017.

Compernolle, S., Ceulemans, K., and Müller, J.-F.: EVAPORATION: a new vapour pressure estimation methodfor organic molecules including non-additivity and intramolecular interactions, Atmos. Chem. Phys., 11, 9431-9450, https://doi.org/10.5194/acp-11-9431-2011, 2011.

D’Ambro, E. L., Schobesberger, S., Gaston, C. J., Lopez-Hilfiker, F. D., Lee, B. H., Liu, J., Zelenyuk, A., Bell, D., Cappa, C. D., Helgestad, T., Li, Z., Guenther, A., Wang, J., Wise, M., Caylor, R., Surratt, J. D., Riedel, T., Hyttinen, N., Salo, V.T., Hasan, G., Kurtén, T., Shilling, J. E., and Thornton, J. A.: Chamber-based insights into the factors controlling epoxydiol (IEPOX) secondary organic aerosol (SOA) yield, composition, and volatility, Atmos. Chem. Phys., 19, 11253-11265, https://doi.org/10.5194/acp-19-11253-2019, 2019.

DeRieux, W.-S. W., Li, Y., Lin, P., Laskin, J., Laskin, A., Bertram, A. K., Nizkorodov, S. A., and Shiraiwa, M.: Predicting the glass transition temperature and viscosity of secondary organic material using molecular composition, Atmos. Chem. Phys., 18, 6331-6351, https://doi.org/10.5194/acp-18-6331-2018, 2018.

DeRieux, W.-S. W., Lakey, P. S. J., Chu, Y., Chan, C. K. K., Glicker, H., Smith, J. N., Zuend, A., and Shiraiwa, M.: Effects of phase state and phase separation on dimethylamine uptake of ammonium sulfate and ammonium sulfate-sucrose mixed particles, ACS Earth Space Chem., 3, 1268-1278, https://doi.org/10.1021/acsearthspacechem.9b00142, 2019.

Dette, H. P., Qi, M., Schröder, D. C., Godt, A., and Koop, T.: Glass-forming properties of 3-methylbutane-1,2,3-tricarboxylic acid and its mixtures with water and pinonic acid, J. Phys. Chem. A, 118, 7024-7033, https://doi.org/10.1021/jp505910w, 2014.

Dette, H. P. and Koop, T.: Glass formation processes in mixed inorganic/organic aerosol particles, J. Phys. Chem. A, 119, 45524561, https://doi.org/10.1021/jp5106967, 2015.

Ditto, J. C., Barnes, E. B., Khare, P., Takeuchi, M., Joo, T., Bui, A. A. T., Lee-Taylor, J., Eris, G., Chen, Y., Aumont, B., Jimenez, J. L., Ng, N. L., Griffin, R. J., and Gentner, D. R.: An omnipresent diversity and variability in the chemical composition of atmospheric functionalized organic aerosol, Commun. Chem., 1, 75, https://doi.org/10.1038/s42004-018-0074-3, 2018.

Ditto, J. C., Joo, T., Khare, P., Sheu, R., Takeuchi, M., Chen, Y., Xu, W., Bui, A. A. T., Sun, Y., Ng, N. L. S., and Gentner, D. R.: Effects of molecular-level compositional variability in organic aerosol on phase state and thermodynamic mixing behavior, Environ. Sci. Technol., 53, 13009-13018, https://doi.org/10.1021/acs.est.9b02664, 2019.

Donahue, N., Robinson, A., Stanier, C., and Pandis, S.: Coupled partitioning, dilution, and chemical aging of semivolatile organics, Environ. Sci. Technol., 40, 2635-2643, https://doi.org/10.1021/es052297c, 2006.

Donahue, N. M., Epstein, S. A., Pandis, S. N., and Robinson, A. L.: A two-dimensional volatility basis set: 1. organic-aerosol mixing thermodynamics, Atmos. Chem. Phys., 11, 3303-3318, https://doi.org/10.5194/acp-11-3303-2011, 2011.

Evoy, E., Maclean, A. M., Rovelli, G., Li, Y., Tsimpidi, A. P., Karydis, V. A., Kamal, S., Lelieveld, J., Shiraiwa, M., Reid, J. P., and Bertram, A. K.: Predictions of diffusion rates of large organic molecules in secondary organic aerosols using the StokesEinstein and fractional Stokes-Einstein relations, Atmos. Chem. Phys., 19, 10073-10085, https://doi.org/10.5194/acp-19-100732019, 2019.

Faulhaber, A. E., Thomas, B. M., Jimenez, J. L., Jayne, J. T., Worsnop, D. R., and Ziemann, P. J.: Characterization of a thermodenuder-particle beam mass spectrometer system for the study of organic aerosol volatility and composition, Atmos. Meas. Tech., 2, 15-31, https://doi.org/10.5194/amt-2-15-2009, 2009.

Freedman, M. A.: Phase separation in organic aerosol, Chem. Soc. Rev., 46, 7694-7705, https://doi.org/10.1039/c6cs00783j, 2017.

Gervasi, N. R., Topping, D. O., and Zuend, A.: A predictive group-contribution model for the viscosity of aqueous organic aerosol, Atmos. Chem. Phys., 20, 2987-3008, https://doi.org/10.5194/acp-20-2987-2020, 2020.

Goldstein, A. H. and Galbally, I. E.: Known and unexplored organic constituents in the Earth's atmosphere, Environ. Sci. Technol., 41, 1514-1521, https://doi.org/10.1021/es072476p, 2007.

Gordon, M. and Taylor, J. S.: Ideal copolymers and the second-order transitions of synthetic rubbers. i. noncrystalline copolymers, J. Appl. Chem., 2, 493-500, https://doi.org/10.1002/jctb.5010020901, 1952.

Gorkowski, K., Preston, T. C., and Zuend, A.: Relative-humiditydependent organic aerosol thermodynamics via an efficient reduced-complexity model, Atmos. Chem. Phys., 19, 1338313407, https://doi.org/10.5194/acp-19-13383-2019, 2019a.

Gorkowski, K., Donahue, N. M., and Sullivan, R. C.: Aerosol optical tweezers constrain the morphology evolution of liquidliquid phase-separated atmospheric particles, Chem, 6, 1-17, https://doi.org/10.1016/j.chempr.2019.10.018, 2019b.

Grayson, J. W., Zhang, Y., Mutzel, A., Renbaum-Wolff, L., Böge, O., Kamal, S., Herrmann, H., Martin, S. T., and Bertram, A. K.: Effect of varying experimental conditions on the viscosity of $\alpha$-pinene derived secondary organic material, Atmos. Chem. Phys., 16, 6027-6040, https://doi.org/10.5194/acp-166027-2016, 2016.

Hallquist, M., Wenger, J. C., Baltensperger, U., Rudich, Y., Simpson, D., Claeys, M., Dommen, J., Donahue, N. M., George, C., Goldstein, A. H., Hamilton, J. F., Herrmann, H., Hoffmann, T., Iinuma, Y., Jang, M., Jenkin, M. E., Jimenez, J. L., Kiendler-Scharr, A., Maenhaut, W., McFiggans, G., Mentel, Th. F., Monod, A., Prévôt, A. S. H., Seinfeld, J. H., Surratt, J. D., Szmigielski, R., and Wildt, J.: The formation, properties and impact of secondary organic aerosol: current and emerging issues, Atmos. Chem. Phys., 9, 5155-5236, https://doi.org/10.5194/acp9-5155-2009, 2009.

Hu, W. W., Campuzano-Jost, P., Palm, B. B., Day, D. A., Ortega, A. M., Hayes, P. L., Krechmer, J. E., Chen, Q., Kuwata, M., Liu, Y. J., de Sá, S. S., McKinney, K., Martin, S. T., Hu, M., Budisulistiorini, S. H., Riva, M., Surratt, J. D., St. Clair, J. M., Isaacman-Van Wertz, G., Yee, L. D., Goldstein, A. H., Carbone, S., Brito, J., Artaxo, P., de Gouw, J. A., Koss, A., Wisthaler, A., Mikoviny, T., Karl, T., Kaser, L., Jud, W., Hansel, A., Docherty, K. S., Alexander, M. L., Robinson, N. H., Coe, H., Allan, J. D., Canagaratna, M. R., Paulot, F., and Jimenez, J. L.: Characterization of a real-time tracer for isoprene epoxydiols-derived secondary organic aerosol (IEPOX-SOA) from aerosol mass spec- 
trometer measurements, Atmos. Chem. Phys., 15, 11807-11833, https://doi.org/10.5194/acp-15-11807-2015, 2015.

Hu, W., Palm, B. B., Day, D. A., Campuzano-Jost, P., Krechmer, J. E., Peng, Z., de Sá, S. S., Martin, S. T., Alexander, M. L., Baumann, K., Hacker, L., Kiendler-Scharr, A., Koss, A. R., de Gouw, J. A., Goldstein, A. H., Seco, R., Sjostedt, S. J., Park, J.-H., Guenther, A. B., Kim, S., Canonaco, F., Prévôt, A. S. H., Brune, W. H., and Jimenez, J. L.: Volatility and lifetime against $\mathrm{OH}$ heterogeneous reaction of ambient isoprene-epoxydiolsderived secondary organic aerosol (IEPOX-SOA), Atmos. Chem. Phys., 16, 11563-11580, https://doi.org/10.5194/acp-16-115632016, 2016.

Jain, S., Fischer, B. K., and Petrucci, A. G.: The Influence of absolute mass loading of secondary organic aerosols on their phase state, Atmosphere, 9, 131, https://doi.org/10.3390/atmos9040131, 2018.

Jimenez, J. L., Canagaratna, M. R., Donahue, N. M., Prevot, A. S. H., Zhang, Q., Kroll, J. H., DeCarlo, P. F., Allan, J. D., Coe, H., Ng, N. L., Aiken, A. C., Docherty, K. S., Ulbrich, I. M., Grieshop, A. P., Robinson, A. L., Duplissy, J., Smith, J. D., Wilson, K. R., Lanz, V. A., Hueglin, C., Sun, Y. L., Tian, J., Laaksonen, A., Raatikainen, T., Rautiainen, J., Vaattovaara, P., Ehn, M., Kulmala, M., Tomlinson, J. M., Collins, D. R., Cubison, M. J., Dunlea, E. J., Huffman, J. A., Onasch, T. B., Alfarra, M. R., Williams, P. I., Bower, K., Kondo, Y., Schneider, J., Drewnick, F., Borrmann, S., Weimer, S., Demerjian, K., Salcedo, D., Cottrell, L., Griffin, R., Takami, A., Miyoshi, T., Hatakeyama, S., Shimono, A., Sun, J. Y., Zhang, Y. M., Dzepina, K., Kimmel, J. R., Sueper, D., Jayne, J. T., Herndon, S. C., Trimborn, A. M., Williams, L. R., Wood, E. C., Middlebrook, A. M., Kolb, C. E., Baltensperger, U., and Worsnop, D. R.: Evolution of organic aerosols in the atmosphere, Science, 326, 1525-1529, https://doi.org/10.1126/science.1180353, 2009.

Jöckel, P., Tost, H., Pozzer, A., Brühl, C., Buchholz, J., Ganzeveld, L., Hoor, P., Kerkweg, A., Lawrence, M. G., Sander, R., Steil, B., Stiller, G., Tanarhte, M., Taraborrelli, D., van Aardenne, J., and Lelieveld, J.: The atmospheric chemistry general circulation model ECHAM5/MESSy1: consistent simulation of ozone from the surface to the mesosphere, Atmos. Chem. Phys., 6, 50675104, https://doi.org/10.5194/acp-6-5067-2006, 2006.

Kanakidou, M., Seinfeld, J. H., Pandis, S. N., Barnes, I., Dentener, F. J., Facchini, M. C., Van Dingenen, R., Ervens, B., Nenes, A., Nielsen, C. J., Swietlicki, E., Putaud, J. P., Balkanski, Y., Fuzzi, S., Horth, J., Moortgat, G. K., Winterhalter, R., Myhre, C. E. L., Tsigaridis, K., Vignati, E., Stephanou, E. G., and Wilson, J.: Organic aerosol and global climate modelling: a review, Atmos. Chem. Phys., 5, 1053-1123, https://doi.org/10.5194/acp-5-10532005, 2005.

Kauzmann, W.: The nature of the glassy state and the behavior of liquids at low temperatures, Chem. Rev., 43, 219-256, https://doi.org/10.1021/cr60135a002, 1948.

Kidd, C., Perraud, V., Wingen, L. M., and Finlayson-Pitts, B. J.: Integrating phase and composition of secondary organic aerosol from the ozonolysis of alpha-pinene, P. Natl. Acad. Sci. USA, 111, 7552-7557, https://doi.org/10.1073/pnas.1322558111, 2014.

Knopf, D. A., Alpert, P. A., and Wang, B.: The role of organic aerosol in atmospheric ice nucleation: a review, ACS Earth Space Chem., 2, 168-202, https://doi.org/10.1021/acsearthspacechem.7b00120, 2018.

Kohl, I., Bachmann, L., Hallbrucker, A., Mayer, E., and Loerting, T.: Liquid-like relaxation in hyperquenched water at $\leq 140 \mathrm{~K}$, Phys. Chem. Chem. Phys., 7, 3210-3220, https://doi.org/10.1039/B507651J, 2005.

Koop, T., Bookhold, J., Shiraiwa, M., and Pöschl, U.: Glass transition and phase state of organic compounds: dependency on molecular properties and implications for secondary organic aerosols in the atmosphere, Phys. Chem. Chem. Phys., 13, 19238-19255, https://doi.org/10.1039/C1CP22617G, 2011.

Kostenidou, E., Karnezi, E., Hite Jr., J. R., Bougiatioti, A., Cerully, K., Xu, L., Ng, N. L., Nenes, A., and Pandis, S. N.: Organic aerosol in the summertime southeastern United States: components and their link to volatility distribution, oxidation state and hygroscopicity, Atmos. Chem. Phys., 18, 5799-5819, https://doi.org/10.5194/acp-18-5799-2018, 2018.

Krechmer, J. E., Day, D. A., Ziemann, P. J., and Jimenez, J. L.: Direct measurements of gas/particle partitioning and mass accommodation coefficients in environmental chambers, Environ. Sci. Technol., 51, 11867-11875, https://doi.org/10.1021/acs.est.7b02144, 2017.

Krieger, U. K., Marcolli, C., and Reid, J. P.: Exploring the complexity of aerosol particle properties and processes using single particle techniques, Chem. Soc. Rev., 41, 6631-6662, https://doi.org/10.1039/C2CS35082C, 2012.

Lambe, A. T., Onasch, T. B., Massoli, P., Croasdale, D. R., Wright, J. P., Ahern, A. T., Williams, L. R., Worsnop, D. R., Brune, W. H., and Davidovits, P.: Laboratory studies of the chemical composition and cloud condensation nuclei $(\mathrm{CCN})$ activity of secondary organic aerosol (SOA) and oxidized primary organic aerosol (OPOA), Atmos. Chem. Phys., 11, 8913-8928, https://doi.org/10.5194/acp-11-8913-2011, 2011.

Lanz, V. A., Alfarra, M. R., Baltensperger, U., Buchmann, B., Hueglin, C., and Prévôt, A. S. H.: Source apportionment of submicron organic aerosols at an urban site by factor analytical modelling of aerosol mass spectra, Atmos. Chem. Phys., 7, 15031522, https://doi.org/10.5194/acp-7-1503-2007, 2007.

Lee, B.-H., Pierce, J. R., Engelhart, G. J., and Pandis, S. N.: Volatility of secondary organic aerosol from the ozonolysis of monoterpenes, Atmos. Environ., 45, 2443-2452, https://doi.org/10.1016/j.atmosenv.2011.02.004, 2011.

Lessmeier, J., Dette, H. P., Godt, A., and Koop, T.: Physical state of 2-methylbutane-1,2,3,4-tetraol in pure and internally mixed aerosols, Atmos. Chem. Phys., 18, 15841-15857, https://doi.org/10.5194/acp-18-15841-2018, 2018.

Li, Y. and Shiraiwa, M.: Timescales of secondary organic aerosols to reach equilibrium at various temperatures and relative humidities, Atmos. Chem. Phys., 19, 5959-5971, https://doi.org/10.5194/acp-19-5959-2019, 2019.

Li, Y., Pöschl, U., and Shiraiwa, M.: Molecular corridors and parameterizations of volatility in the chemical evolution of organic aerosols, Atmos. Chem. Phys., 16, 3327-3344, https://doi.org/10.5194/acp-16-3327-2016, 2016.

Lin, Y.-H., Zhang, Z., Docherty, K. S., Zhang, H., Budisulistiorini, S. H., Rubitschun, C. L., Shaw, S. L., Knipping, E. M., Edgerton, E. S., Kleindienst, T. E., Gold, A., and Surratt, J. D.: Isoprene epoxydiols as precursors to secondary organic aerosol formation: acid-catalyzed reactive uptake studies 
with authentic compounds, Environ. Sci. Technol., 46, 250-258, https://doi.org/10.1021/es202554c, 2012.

Lin, Y.-H., Zhang, H., Pye, H. O. T., Zhang, Z., Marth, W. J., Park, S., Arashiro, M., Cui, T., Budisulistiorini, S. H., Sexton, K. G., Vizuete, W., Xie, Y., Luecken, D. J., Piletic, I. R., Edney, E. O., Bartolotti, L. J., Gold, A., and Surratt, J. D.: Epoxide as a precursor to secondary organic aerosol formation from isoprene photooxidation in the presence of nitrogen oxides, P. Natl. Acad. Sci. USA, 110, 6718-6723, https://doi.org/10.1073/pnas.1221150110, 2013.

Liu, P., Li, Y. J., Wang, Y., Gilles, M. K., Zaveri, R. A., Bertram, A. K., and Martin, S. T.: Lability of secondary organic particulate matter, P. Natl. Acad. Sci. USA, 113, 12643-12648, https://doi.org/10.1073/pnas.1603138113, 2016.

Liu, X., Day, D. A., Krechmer, J. E., Brown, W., Peng, Z., Ziemann, P. J., and Jimenez, J. L.: Direct measurements of semi-volatile organic compound dynamics show near-unity mass accommodation coefficients for diverse aerosols, Commun. Chem., 2, 98, https://doi.org/10.1038/s42004-019-0200-x, 2019.

Liu, Y., Wu, Z., Wang, Y., Xiao, Y., Gu, F., Zheng, J., Tan, T., Shang, D., Wu, Y., Zeng, L., Hu, M., Bateman, A. P., and Martin, S. T.: Submicrometer particles are in the liquid state during heavy haze episodes in the urban atmosphere of Beijing, China, Environ. Sci. Tech. Let., 4, 427-432, https://doi.org/10.1021/acs.estlett.7b00352, 2017.

Lopez-Hilfiker, F. D., Mohr, C., Ehn, M., Rubach, F., Kleist, E., Wildt, J., Mentel, Th. F., Lutz, A., Hallquist, M., Worsnop, D., and Thornton, J. A.: A novel method for online analysis of gas and particle composition: description and evaluation of a Filter Inlet for Gases and AEROsols (FIGAERO), Atmos. Meas. Tech., 7, 983-1001, https://doi.org/10.5194/amt-7-983-2014, 2014.

Lopez-Hilfiker, F. D., Mohr, C., D’Ambro, E. L., Lutz, A., Riedel, T. P., Gaston, C. J., Iyer, S., Zhang, Z., Gold, A., Surratt, J. D., Lee, B. H., Kurten, T., Hu, W. W., Jimenez, J., Hallquist, M., and Thornton, J. A.: Molecular composition and volatility of organic aerosol in the southeastern U.S.: implications for IEPOX derived SOA, Environ. Sci. Technol., 50, 2200-2209, https://doi.org/10.1021/acs.est.5b04769, 2016.

Louvaris, E. E., Florou, K., Karnezi, E., Papanastasiou, D. K., Gkatzelis, G. I., and Pandis, S. N.: Volatility of source apportioned wintertime organic aerosol in the city of Athens, Atmos. Environ., 158, 138-147, https://doi.org/10.1016/j.atmosenv.2017.03.042, 2017.

Loza, C. L., Coggon, M. M., Nguyen, T. B., Zuend, A., Flagan, R. C., and Seinfeld, J. H.: On the mixing and evaporation of secondary organic aerosol components, Environ. Sci. Technol., 47, 6173-6180, https://doi.org/10.1021/es400979k, 2013.

Marshall, F. H., Berkemeier, T., Shiraiwa, M., Nandy, L., Ohm, P. B., Dutcher, C. S., and Reid, J. P.: Influence of particle viscosity on mass transfer and heterogeneous ozonolysis kinetics in aqueous-sucrose-maleic acid aerosol, Phys. Chem. Chem. Phys., 20, 15560-15573, https://doi.org/10.1039/c8cp01666f, 2018.

Mikhailov, E., Vlasenko, S., Martin, S. T., Koop, T., and Pöschl, U.: Amorphous and crystalline aerosol particles interacting with water vapor: conceptual framework and experimental evidence for restructuring, phase transitions and kinetic limitations, Atmos. Chem. Phys., 9, 9491-9522, https://doi.org/10.5194/acp-9-94912009, 2009.
Nizkorodov, S. A., Laskin, J., and Laskin, A.: Molecular chemistry of organic aerosols through the application of high resolution mass spectrometry, Phys. Chem. Chem. Phys., 13, 3612-3629, https://doi.org/10.1039/c0cp02032j, 2011.

O’Brien, R. E., Neu, A., Epstein, S. A., MacMillan, A. C., Wang, B., Kelly, S. T., Nizkorodov, S. A., Laskin, A., Moffet, R. C., and Gilles, M. K.: Physical properties of ambient and laboratorygenerated secondary organic aerosol, Geophys. Res. Lett., 41, 4347-4353, https://doi.org/10.1002/2014GL060219, 2014.

O'Meara, S., Booth, A. M., Barley, M. H., Topping, D., and McFiggans, G.: An assessment of vapour pressure estimation methods, Phys. Chem. Chem. Phys., 16, 19453-19469, https://doi.org/10.1039/c4cp00857j, 2014

Ortega, A. M., Hayes, P. L., Peng, Z., Palm, B. B., Hu, W., Day, D. A., Li, R., Cubison, M. J., Brune, W. H., Graus, M., Warneke, C., Gilman, J. B., Kuster, W. C., de Gouw, J., GutiérrezMontes, C., and Jimenez, J. L.: Real-time measurements of secondary organic aerosol formation and aging from ambient air in an oxidation flow reactor in the Los Angeles area, Atmos. Chem. Phys., 16, 7411-7433, https://doi.org/10.5194/acp16-7411-2016, 2016.

Paciga, A., Karnezi, E., Kostenidou, E., Hildebrandt, L., Psichoudaki, M., Engelhart, G. J., Lee, B.-H., Crippa, M., Prévôt, A. S. H., Baltensperger, U., and Pandis, S. N.: Volatility of organic aerosol and its components in the megacity of Paris, Atmos. Chem. Phys., 16, 2013-2023, https://doi.org/10.5194/acp16-2013-2016, 2016.

Pajunoja, A., Malila, J., Hao, L., Joutsensaari, J., Lehtinen, K. E., and Virtanen, A.: Estimating the viscosity range of SOA particles based on their coalescence time, Aerosol Sci. Tech., 48, i-iv, https://doi.org/10.1080/02786826.2013.870325, 2014.

Pajunoja, A., Hu, W., Leong, Y. J., Taylor, N. F., Miettinen, P., Palm, B. B., Mikkonen, S., Collins, D. R., Jimenez, J. L., and Virtanen, A.: Phase state of ambient aerosol linked with water uptake and chemical aging in the southeastern US, Atmos. Chem. Phys., 16, 11163-11176, https://doi.org/10.5194/acp-16-111632016, 2016.

Pankow, J. F.: An absorption model of gas-particle partitioning of organic-compounds in the atmosphere, Atmos. Environ., 28, 185-188, https://doi.org/10.1016/1352-2310(94)90093-0, 1994.

Pankow, J. F. and Asher, W. E.: SIMPOL.1: a simple group contribution method for predicting vapor pressures and enthalpies of vaporization of multifunctional organic compounds, Atmos. Chem. Phys., 8, 2773-2796, https://doi.org/10.5194/acp-8-27732008, 2008.

Perraud, V., Bruns, E. A., Ezell, M. J., Johnson, S. N., Yu, Y., Alexander, M. L., Zelenyuk, A., Imre, D., Chang, W. L., Dabdub, D., Pankow, J. F., and Finlayson-Pitts, B. J.: Nonequilibrium atmospheric secondary organic aerosol formation and growth, P. Natl. Acad. Sci. USA, 109, 2836-2841, https://doi.org/10.1073/pnas.1119909109, 2012.

Petters, M. D. and Kreidenweis, S. M.: A single parameter representation of hygroscopic growth and cloud condensation nucleus activity, Atmos. Chem. Phys., 7, 1961-1971, https://doi.org/10.5194/acp-7-1961-2007, 2007.

Petters, S. S., Kreidenweis, S. M., Grieshop, A. P., Ziemann, P. J., and Petters, M. D.: Temperature- and humidity-dependent phase states of secondary organic aerosols, Geophys. Res. Lett., 46, 1005-1013, https://doi.org/10.1029/2018GL080563, 2019. 
Pöschl, U. and Shiraiwa, M.: Multiphase chemistry at the atmosphere-biosphere interface influencing climate and public health in the anthropocene, Chem. Rev., 115, 4440-4475, https://doi.org/10.1021/cr500487s, 2015.

Price, H. C., Mattsson, J., and Murray, B. J.: Sucrose diffusion in aqueous solution, Phys. Chem. Chem. Phys., 18, 19207-19216, https://doi.org/10.1039/c6cp03238a, 2016.

Pringle, K. J., Tost, H., Pozzer, A., Pöschl, U., and Lelieveld, J.: Global distribution of the effective aerosol hygroscopicity parameter for CCN activation, Atmos. Chem. Phys., 10, 52415255, https://doi.org/10.5194/acp-10-5241-2010, 2010.

Pye, H. O. T., Murphy, B. N., Xu, L., Ng, N. L., Carlton, A. G., Guo, H., Weber, R., Vasilakos, P., Appel, K. W., Budisulistiorini, S. H., Surratt, J. D., Nenes, A., Hu, W., Jimenez, J. L., Isaacman-VanWertz, G., Misztal, P. K., and Goldstein, A. H.: On the implications of aerosol liquid water and phase separation for organic aerosol mass, Atmos. Chem. Phys., 17, 343-369, https://doi.org/10.5194/acp-17-343-2017, 2017.

Reid, J. P., Bertram, A. K., Topping, D. O., Laskin, A., Martin, S. T., Petters, M. D., Pope, F. D., and Rovelli, G.: The viscosity of atmospherically relevant organic particles, Nat. Commun., 9, 956, https://doi.org/10.1038/s41467-018-03027-z, 2018.

Renbaum-Wolff, L., Grayson, J. W., Bateman, A. P., Kuwata, M., Sellier, M., Murray, B. J., Shilling, J. E., Martin, S. T., and Bertram, A. K.: Viscosity of $\alpha$-pinene secondary organic material and implications for particle growth and reactivity, P. Natl. Acad. Sci. USA, 110, 8014-8019, https://doi.org/10.1073/pnas.1219548110, 2013.

Riva, M., Chen, Y., Zhang, Y., Lei, Z., Olson, N. E., Boyer, H. C., Narayan, S., Yee, L. D., Green, H. S., Cui, T., Zhang, Z., Baumann, K., Fort, M., Edgerton, E., Budisulistiorini, S. H., Rose, C. A., Ribeiro, I. O., e Oliveira, R. L., dos Santos, E. O., Machado, C. M. D., Szopa, S., Zhao, Y., Alves, E. G., de Sá, S. S., Hu, W., Knipping, E. M., Shaw, S. L., Duvoisin Junior, S., de Souza, R. A. F., Palm, B. B., Jimenez, J.-L., Glasius, M., Goldstein, A. H., Pye, H. O. T., Gold, A., Turpin, B. J., Vizuete, W., Martin, S. T., Thornton, J. A., Dutcher, C. S., Ault, A. P., and Surratt, J. D.: Increasing isoprene epoxydiol-toinorganic sulfate aerosol ratio results in extensive conversion of inorganic sulfate to organosulfur forms: implications for aerosol physicochemical properties, Environ. Sci. Technol., 53, 86828694, https://doi.org/10.1021/acs.est.9b01019, 2019.

Rothfuss, N. E. and Petters, M. D.: Influence of functional groups on the viscosity of organic aerosol, Environ. Sci. Technol., 51, 271-279, https://doi.org/10.1021/acs.est.6b04478, 2017.

Rovelli, G., Song, Y.-C., Maclean, A. M., Topping, D. O., Bertram, A. K.. and Reid, J. P.: Comparison of approaches for measuring and predicting the viscosity of ternary component aerosol particles, Anal. Chem., 91, 5074-5082, https://doi.org/10.1021/acs.analchem.8b05353, 2019.

Saha, P. K., Khlystov, A., Yahya, K., Zhang, Y., Xu, L., Ng, N. L., and Grieshop, A. P.: Quantifying the volatility of organic aerosol in the southeastern US, Atmos. Chem. Phys., 17, 501520, https://doi.org/10.5194/acp-17-501-2017, 2017.

Saha, P. K., Khlystov, A., and Grieshop, A. P.: Downwind evolution of the volatility and mixing state of near-road aerosols near a US interstate highway, Atmos. Chem. Phys., 18, 2139-2154, https://doi.org/10.5194/acp-18-2139-2018, 2018.
Saukko, E., Lambe, A. T., Massoli, P., Koop, T., Wright, J. P., Croasdale, D. R., Pedernera, D. A., Onasch, T. B., Laaksonen, A., Davidovits, P., Worsnop, D. R., and Virtanen, A.: Humiditydependent phase state of SOA particles from biogenic and anthropogenic precursors, Atmos. Chem. Phys., 12, 7517-7529, https://doi.org/10.5194/acp-12-7517-2012, 2012.

Schmedding, R., Rasool, Q. Z., Zhang, Y., Pye, H. O. T., Zhang, H., Chen, Y., Surratt, J. D., Lee, B. H., Mohr, C., LopezHilfiker, F. D., Thornton, J. A., Goldstein, A. H., and Vizuete, W.: Predicting Secondary Organic Aerosol Phase State and Viscosity and its Effect on Multiphase Chemistry in a Regional Scale Air Quality Model, Atmos. Chem. Phys. Discuss., https://doi.org/10.5194/acp-2019-900, in review, 2019.

Schum, S. K., Zhang, B., Džepina, K., Fialho, P., Mazzoleni, C., and Mazzoleni, L. R.: Molecular and physical characteristics of aerosol at a remote free troposphere site: implications for atmospheric aging, Atmos. Chem. Phys., 18, 14017-14036, https://doi.org/10.5194/acp-18-14017-2018, 2018.

Seinfeld, J. H. and Pandis, S. N.: Atmospheric chemistry and physics - From air pollution to climate change, John Wiley \& Sons, Inc., New York, 2006.

Shiraiwa, M. and Seinfeld, J. H.: Equilibration timescale of atmospheric secondary organic aerosol partitioning, Geophys. Res. Lett., 39, L24801, https://doi.org/10.1029/2012GL054008, 2012.

Shiraiwa, M., Ammann, M., Koop, T., and Pöschl, U.: Gas uptake and chemical aging of semisolid organic aerosol particles, P. Natl. Acad. Sci. USA, 108, 11003-11008, https://doi.org/10.1073/pnas.1103045108, 2011.

Shiraiwa, M., Zuend, A., Bertram, A. K., and Seinfeld, J. H.: Gasparticle partitioning of atmospheric aerosols: interplay of physical state, non-ideal mixing and morphology, Phys. Chem. Chem. Phys., 15, 11441-11453, https://doi.org/10.1039/C3CP51595H, 2013.

Shiraiwa, M., Berkemeier, T., Schilling-Fahnestock, K. A., Seinfeld, J. H., and Pöschl, U.: Molecular corridors and kinetic regimes in the multiphase chemical evolution of secondary organic aerosol, Atmos. Chem. Phys., 14, 8323-8341, https://doi.org/10.5194/acp-14-8323-2014, 2014.

Shiraiwa, M., Li, Y., Tsimpidi, A. P., Karydis, V. A., Berkemeier, T., Pandis, S. N., Lelieveld, J., Koop, T., and Pöschl, U.: Global distribution of particle phase state in atmospheric secondary organic aerosols, Nat. Commun., 8, 15002, https://doi.org/10.1038/ncomms15002, 2017.

Shrivastava, M., Cappa, C. D., Fan, J., Goldstein, A. H., Guenther, A. B., Jimenez, J. L., Kuang, C., Laskin, A., Martin, S. T., Ng, N. L., Petaja, T., Pierce, J. R., Rasch, P. J., Roldin, P., Seinfeld, J. H., Shilling, J., Smith, J. N., Thornton, J. A., Volkamer, R., Wang, J., Worsnop, D. R., Zaveri, R. A., Zelenyuk, A., and Zhang, Q.: Recent advances in understanding secondary organic aerosol: Implications for global climate forcing, Rev. Geophys., 55, 509559, https://doi.org/10.1002/2016RG000540, 2017.

Slade, J. H., Ault, A. P., Bui, A. T., Ditto, J. C., Lei, Z., Bondy, A. L., Olson, N. E., Cook, R. D., Desrochers, S. J., Harvey, R. M., Erickson, M. H., Wallace, H. W., Alvarez, S. L., Flynn, J. H., Boor, B. E., Petrucci, G. A., Gentner, D. R., Griffin, R. J., and Shepson, P. B.: Bouncier particles at night: biogenic secondary organic aerosol chemistry and sulfate drive diel variations in the aerosol phase in a mixed forest, Environ. Sci. Technol., 53, 49774987, https://doi.org/10.1021/acs.est.8b07319, 2019. 
Song, M., Liu, P. F., Hanna, S. J., Li, Y. J., Martin, S. T., and Bertram, A. K.: Relative humidity-dependent viscosities of isoprene-derived secondary organic material and atmospheric implications for isoprene-dominant forests, Atmos. Chem. Phys., 15, 5145-5159, https://doi.org/10.5194/acp-155145-2015, 2015.

Song, M., Liu, P. F., Hanna, S. J., Zaveri, R. A., Potter, K., You, Y., Martin, S. T., and Bertram, A. K.: Relative humiditydependent viscosity of secondary organic material from toluene photo-oxidation and possible implications for organic particulate matter over megacities, Atmos. Chem. Phys., 16, 8817-8830, https://doi.org/10.5194/acp-16-8817-2016, 2016.

Song, M., Maclean, A. M., Huang, Y., Smith, N. R., Blair, S. L., Laskin, J., Laskin, A., DeRieux, W.-S. W., Li, Y., Shiraiwa, M., Nizkorodov, S. A., and Bertram, A. K.: Liquid-liquid phase separation and viscosity within secondary organic aerosol generated from diesel fuel vapors, Atmos. Chem. Phys., 19, 12515-12529, https://doi.org/10.5194/acp-19-12515-2019, 2019.

Song, Y. C., Haddrell, A. E., Bzdek, B. R., Reid, J. P., Bannan, T., Topping, D. O., Percival, C., and Cai, C.: Measurements and predictions of binary component aerosol particle viscosity, J. Phys. Chem. A, 120, 8123-8137, https://doi.org/10.1021/acs.jpca.6b07835, 2016.

Stark, H., Yatavelli, R. L. N., Thompson, S. L., Kimmel, J. R., Cubison, M. J., Chhabra, P. S., Canagaratna, M. R., Jayne, J. T., Worsnop, D. R., and Jimenez, J. L.: Methods to extract molecular and bulk chemical information from series of complex mass spectra with limited mass resolution, Int. J. Mass Spectrom., 389, 26-38, https://doi.org/10.1016/j.ijms.2015.08.011, 2015.

Stark, H., Yatavelli, R. L., Thompson, S. L., Kang, H., Krechmer, J. E., Kimmel, J. R., Palm, B. B., Hu, W., Hayes, P. L., and Day, D. A.: Impact of thermal decomposition on thermal desorption instruments: advantage of thermogram analysis for quantifying volatility distributions of organic species, Environ. Sci. Technol., 51, 8491-8500, https://doi.org/10.1021/acs.est.7b00160, 2017.

Surratt, J. D., Chan, A. W. H., Eddingsaas, N. C., Chan, M., Loza, C. L., Kwan, A. J., Hersey, S. P., Flagan, R. C., Wennberg, P. O., and Seinfeld, J. H.: Reactive intermediates revealed in secondary organic aerosol formation from isoprene, P. Natl. Acad. Sci. USA, 107, 6640-6645, https://doi.org/10.1073/pnas.0911114107, 2010.

Thomas, L. H., Meatyard, R., Smith, H., and Davies, G. H.: Viscosity behavior of associated liquids at lower temperatures and vapor pressures, J. Chem. Eng. Data, 24, 161-164, https://doi.org/10.1021/je60082a011, 1979.

Thompson, S. L., Yatavelli, R. L. N., Stark, H., Kimmel, J. R., Krechmer, J. E., Day, D. A., Hu, W., Isaacman-VanWertz, G., Yee, L., Goldstein, A. H., Khan, M. A. H., Holzinger, R., Kreisberg, N., Lopez-Hilfiker, F. D., Mohr, C., Thornton, J. A., Jayne, J. T., Canagaratna, M., Worsnop, D. R., and Jimenez, J. L.: Field intercomparison of the gas/particle partitioning of oxygenated organics during the Southern Oxidant and Aerosol Study (SOAS) in 2013, Aerosol Sci. Tech., 51, 30-56, https://doi.org/10.1080/02786826.2016.1254719, 2017.

Tsimpidi, A. P., Karydis, V. A., Pozzer, A., Pandis, S. N., and Lelieveld, J.: ORACLE (v1.0): module to simulate the organic aerosol composition and evolution in the atmosphere, Geosci. Model Dev., 7, 3153-3172, https://doi.org/10.5194/gmd-7-31532014, 2014.
US EPA: Estimation Programs Interface Suite ${ }^{\mathrm{TM}}$ for Microsoft Windows v4.1, United States Environmental Protection Agency, Washington, DC, USA, 2015.

Vander Wall, A. C., Lakey, P. S. J., Rossich Molina, E., Perraud, V., Wingen, L. M., Xu, J., Soulsby, D., Gerber, R. B., Shiraiwa, M. and Finlayson-Pitts, B. J.: Understanding interactions of organic nitrates with the surface and bulk of organic films: implications for particle growth in the atmosphere, Environ. Sci. Processes Impacts, 20, 1593-1610, https://doi.org/10.1039/C8EM00348C, 2018.

Virtanen, A., Joutsensaari, J., Koop, T., Kannosto, J., YliPirilä, P., Leskinen, J., Mäkelä, J. M., Holopainen, J. K., Pöschl, U., Kulmala, M., Worsnop, D. R., and Laaksonen, A.: An amorphous solid state of biogenic secondary organic aerosol particles, Nature, 467, 824-827, https://doi.org/10.1038/nature09455, 2010.

Xu, L., Suresh, S., Guo, H., Weber, R. J., and Ng, N. L.: Aerosol characterization over the southeastern United States using high-resolution aerosol mass spectrometry: spatial and seasonal variation of aerosol composition and sources with a focus on organic nitrates, Atmos. Chem. Phys., 15, 7307-7336, https://doi.org/10.5194/acp-15-7307-2015, 2015.

Xu, W., Xie, C., Karnezi, E., Zhang, Q., Wang, J., Pandis, S. N., Ge, X., Zhang, J., An, J., Wang, Q., Zhao, J., Du, W., Qiu, Y., Zhou, W., He, Y., Li, Y., Li, J., Fu, P., Wang, Z., Worsnop, D. R., and Sun, Y.: Summertime aerosol volatility measurements in Beijing, China, Atmos. Chem. Phys., 19, 10205-10216, https://doi.org/10.5194/acp-19-10205-2019, 2019.

Yatavelli, R. L. N., Mohr, C., Stark, H., Day, D. A., Thompson, S. L., Lopez-Hilfiker, F. D., Campuzano-Jost, P., Palm, B. B., Vogel, A. L., Hoffmann, T., Heikkinen, L., Äijälä, M., Ng, N. L., Kimmel, J. R., Canagaratna, M. R., Ehn, M., Junninen, H., Cubison, M. J., Petäjä, T., Kulmala, M., Jayne, J. T., Worsnop, D. R., and Jimenez, J. L.: Estimating the contribution of organic acids to northern hemispheric continental organic aerosol, Geophys. Res. Lett., 42, 6084-6090, https://doi.org/10.1002/2015g1064650, 2015.

Ye, Q., Robinson, E. S., Ding, X., Ye, P., Sullivan, R. C., and Donahue, N. M.: Mixing of secondary organic aerosols versus relative humidity, P. Natl. Acad. Sci. USA, 113, 12649-12654, https://doi.org/10.1073/pnas.1604536113, 2016.

Ye, Q., Upshur, M. A., Robinson, E. S., Geiger, F. M., Sullivan, R. C., Thomson, R. J., and Donahue, N. M.: Following particle-particle mixing in atmospheric secondary organic aerosols by using isotopically labeled terpenes, Chem, 4, 318333, https://doi.org/10.1016/j.chempr.2017.12.008, 2018.

Yli-Juuti, T., Pajunoja, A., Tikkanen, O.-P., Buchholz, A., Faiola, C., Väisänen, O., Hao, L., Kari, E., Peräkylä, O., Garmash, O., Shiraiwa, M., Ehn, M., Lehtinen, K., and Virtanen, A.: Factors controlling the evaporation of secondary organic aerosol from $\alpha$-pinene ozonolysis, Geophys. Res. Lett., 44, 2562-2570, https://doi.org/10.1002/2016GL072364, 2017.

Zaveri, R. A., Shilling, J. E., Zelenyuk, A., Liu, J., Bell, D. M., D’Ambro, E. L., Gaston, C. J., Thornton, J. A., Laskin, A., Lin, P., Wilson, J., Easter, R. C., Wang, J., Bertram, A. K., Martin, S. T., Seinfeld, J. H. and Worsnop, D. R.: Growth kinetics and size distribution dynamics of viscous secondary organic aerosol, Environ. Sci. Technol., 52, 1191-1199, https://doi.org/10.1021/acs.est.7b04623, 2018. 
Zhang, Y., Sanchez, M. S., Douet, C., Wang, Y., Bateman, A. P., Gong, Z., Kuwata, M., Renbaum-Wolff, L., Sato, B. B., Liu, P. F., Bertram, A. K., Geiger, F. M., and Martin, S. T.: Changing shapes and implied viscosities of suspended submicron particles, Atmos. Chem. Phys., 15, 7819-7829, https://doi.org/10.5194/acp15-7819-2015, 2015.

Zhang, Y., Katira, S., Lee, A., Lambe, A. T., Onasch, T. B., Xu, W., Brooks, W. A., Canagaratna, M. R., Freedman, A., Jayne, J. T., Worsnop, D. R., Davidovits, P., Chandler, D., and Kolb, C. E.: Kinetically controlled glass transition measurement of organic aerosol thin films using broadband dielectric spectroscopy, Atmos. Meas. Tech., 11, 3479-3490, https://doi.org/10.5194/amt11-3479-2018, 2018.

Zhang, Y., Nichman, L., Spencer, P., Jung, J. I., Lee, A., Heffernan, B. K., Gold, A., Zhang, Z., Chen, Y., Canagaratna, M. R., Jayne, J. T., Worsnop, D. R., Onasch, T. B., Surratt, J. D., Chandler, D., Davidovits, P., and Kolb, C. E.: The cooling rate and volatility dependent glass forming properties of organic aerosols measured by Broadband Dielectric Spectroscopy, Environ. Sci. Technol., 53, 12366-12378, https://doi.org/10.1021/acs.est.9b03317, 2019.
Zhou, S., Hwang, B. C. H., Lakey, P. S. J., Zuend, A., Abbatt, J. P. D., and Shiraiwa, M.: Multiphase reactivity of polycyclic aromatic hydrocarbons is driven by phase separation and diffusion limitations, P. Natl. Acad. Sci. USA, 116, 11658-11663, https://doi.org/10.1073/pnas.1902517116, 2019.

Zobrist, B., Marcolli, C., Pedernera, D. A., and Koop, T.: Do atmospheric aerosols form glasses?, Atmos. Chem. Phys., 8, 52215244, https://doi.org/10.5194/acp-8-5221-2008, 2008.

Zuend, A. and Seinfeld, J. H.: Modeling the gas-particle partitioning of secondary organic aerosol: the importance of liquidliquid phase separation, Atmos. Chem. Phys., 12, 3857-3882, https://doi.org/10.5194/acp-12-3857-2012, 2012. 